\title{
Altitude profiles of cloud condensation nuclei characteristics across the Indo-Gangetic Plain prior to the onset of the Indian summer
} monsoon

\author{
Venugopalan Nair Jayachandran ${ }^{1}$, Surendran Nair Suresh Babu ${ }^{1}$, Aditya Vaishya ${ }^{2}$, Mukunda M. Gogoi ${ }^{1}$, \\ Vijayakumar S. Nair ${ }^{1}$, Sreedharan Krishnakumari Satheesh ${ }^{3,4}$, and Krishnaswamy Krishna Moorthy ${ }^{4}$ \\ ${ }^{1}$ Space Physics Laboratory, Vikram Sarabhai Space Centre, Indian Space Research Organisation (ISRO PO), \\ Thiruvananthapuram, India \\ ${ }^{2}$ School of Arts and Sciences, Ahmedabad University, Ahmedabad, India \\ ${ }^{3}$ Centre for Atmospheric and Oceanic Sciences, Indian Institute of Science, Bengaluru, India \\ ${ }^{4}$ Divecha Centre for Climate Change, Indian Institute of Science, Bengaluru, India
}

Correspondence: Surendran Nair Suresh Babu (sureshsplvssc@gmail.com)

Received: 22 June 2019 - Discussion started: 24 July 2019

Revised: 10 November 2019 - Accepted: 25 November 2019 - Published: 17 January 2020

\begin{abstract}
Concurrent measurements of the altitude profiles of the concentration of cloud condensation nuclei ( $\mathrm{CCN})$, as a function of supersaturation (ranging from $0.2 \%$ to $1.0 \%$ ), and aerosol optical properties (scattering and absorption coefficients) were carried out aboard an instrumented aircraft across the Indo-Gangetic Plain (IGP) just prior to the onset of the Indian summer monsoon (ISM) of 2016. The experiment was conducted under the aegis of the combined South-West Asian Aerosol-Monsoon Interactions and Regional Aerosol Warming Experiment (SWAAMI-RAWEX) campaign. The measurements covered coastal, urban and arid environments. In general, the $\mathrm{CCN}$ concentration was highest in the central IGP, decreasing spatially from east to west above the planetary boundary layer (PBL), which is $\sim 1.5 \mathrm{~km}$ for the IGP during pre-monsoon period. Despite this, the CCN activation efficiency at $0.4 \%$ supersaturation was, interestingly, the highest over the eastern IGP $(\sim 72 \%)$, followed by that in the west $(\sim 61 \%)$, and it was the least over the central IGP $(\sim 24 \%)$ within the PBL. In general, higher activation efficiency is noticed above the PBL than below it. The central IGP showed remarkably low CCN activation efficiency at all altitudes, which appears to be associated with high black carbon (BC) mass concentration there, indicating the role of anthropogenic sources in suppressing the $\mathrm{CCN}$ efficiency. These first-ever CCN measurements over the western IGP, encompassing "the Great Indian Desert" also known as "the Thar Desert", showed high CCN efficiency, 61\% at
\end{abstract}

$0.4 \%$ supersaturation, indicating the hygroscopic nature of the dust. The vertical structure of CCN properties is found to be air mass dependent, with higher activation efficiency even over the central IGP during the prevalence of marine air mass. Wet scavenging associated with precipitation episodes seems to have reduced the $\mathrm{CCN}$ activation efficiency below cloud level. An empirical relation has emerged between the $\mathrm{CCN}$ concentration and the scattering aerosol index (AI), which would facilitate the prediction of $\mathrm{CCN}$ from aerosol optical properties.

\section{Introduction}

The cloud-nucleating ability of aerosols is fundamental in understanding aerosol-cloud interactions (ACIs) and associated feedback processes, which are complex in nature and pose a major challenge in quantifying the indirect climate forcing of aerosols (Boucher et al., 2013; IPCC, 2013). Cloud condensation nuclei (CCN) form a sub-set of atmospheric aerosols (also known as condensation nuclei; $\mathrm{CN}$ ) and take part in cloud processes, accelerate the condensation of water vapour leading to the formation of liquid cloud droplets and modify the microphysical properties of clouds, depending on the number size distribution, chemical composition and mixing state of aerosols (Dusek et al., 2006; Farmer et al., 2015; 
Zhang et al., 2017). Several investigators have examined the temporal and spatial distribution of the $\mathrm{CCN}$ properties and their processing by non-precipitating clouds over both continental and marine environments (Hoppel et al., 1973; Hudson and Xie, 1999; Jurányi et al., 2011; Paramonov et al., 2015; Schmale et al., 2018). Significant variability in the $\mathrm{CCN}$ activation efficiency has also been reported over regions influenced by urban (Sotiropoulou et al., 2007) and industrial emissions (Asa-Awuku et al., 2011). Efforts have also been made to infer or predict $\mathrm{CCN}$ properties based on optical properties (for example, Jefferson, 2010; Liu and $\mathrm{Li}, 2014)$. However, due to the region-specific and heterogeneous nature of the composition of aerosols, their chemical interactions, vertical mixing, and advection to long distances, significant uncertainties still persist in characterising the $\mathrm{CCN}$ activation efficiency, especially its region-specific nature and altitude variation in the real atmosphere (Zhang et al., 2017). The information on the vertical distribution of the $\mathrm{CCN}$ number concentration, $\mathrm{CCN}$ efficiency and its variation with supersaturation are some of the vital parameters needed in quantifying the ACI. In situ measurements of the vertical distribution of the CCN activity especially over polluted regions are very important in accounting for the ACI in climate models (Li et al., 2016).

In the above context, the importance of the South Asian region is unequivocal. Aerosol physicochemical properties show large spatiotemporal variation over this region owing to the diverse source influence, both natural and anthropogenic, which shows large seasonality (Jethwa et al., 2005) and dependence on large-scale meteorology (Lawrence and Lelieveld, 2010; Babu et al., 2013; Nair et al., 2017). Even within South Asia, the Indo-Gangetic Plain (IGP) falls under those regions in the globe where very high aerosol loading persists almost throughout the year (Di Girolamo et al., 2004) and also depicts a steadily increasing trend in aerosol optical depth (AOD) (Dey and Di Girolamo, 2011; Babu et al., 2013), increasing surface dimming (Padma Kumari et al., 2007; Badarinath et al., 2010) and enhanced midtropospheric warming (Satheesh et al., 2008). Through modelling efforts, Vinoj et al. (2014) have shown possible linkages of western Asian dust loading over the Arabian Sea with the Indian summer monsoon (ISM). The competing roles of natural (mostly mineral dust and marine aerosols) and anthropogenic aerosols over this region and their high seasonality, aided by the large-scale industrial and agricultural activities in this region and its particular orography, makes the IGP one of the best natural laboratories for investigating complex aerosol impacts on clouds and precipitation (Moorthy et al., 2016). Despite these, the characterisation of the vertical structure and the spatial variability of $\mathrm{CCN}$ characteristics across the IGP remains quite limited, except for some recent efforts using instrumented aircraft during the summer monsoon season under the Cloud Aerosol Interaction and Precipitation Enhancement Experiment (CAIPEEX) (Prabha et al., 2012; Konwar et al., 2014; Padma Kumari et al., 2017). A few ground-based measurements also exist scattered across the subcontinent (Bhattu and Tripathy, 2014; Gogoi et al., 2015; Jayachandran et al., 2017; Singla et al., 2017).

In light of the above, and with a view to understand the $\mathrm{ACI}$ and its linkage to the ISM, an experimental campaign was undertaken under the aegis of SWAAMI (South-West Asian Aerosol-Monsoon Interactions) and RAWEX (Regional Aerosol Warming Experiment), executed jointly by the Indian Space Research Organisation (ISRO) and the Ministry of Earth Sciences (MoES) of India and the Natural Environment Research Council (NERC) of the UK. Under this, concurrent and co-located airborne measurements of the vertical structure of the CCN characteristics and aerosol scattering and absorption coefficients were carried out across the IGP, just prior to the onset of the ISM. The campaign was planned to quantify the vertical distribution of total aerosols $(\mathrm{CN})$ and $\mathrm{CCN}$ concentrations at different supersaturations and its spatial variation across the IGP, just prior to the onset of the ISM, when different aerosol types are known to coexist over this region. The data are analysed to understand the altitude distribution of $\mathrm{CCN}$ characteristics, its activation efficiency and its relationship with scattering and absorption properties of aerosols as well as the variation of those from west to east across the IGP. The campaign details along with the measurement protocols are given below, followed by the results and discussions.

\section{Experiment details, data and analysis}

\subsection{Campaign}

Airborne measurements of the $\mathrm{CCN}$ number concentration as a function of supersaturation $(0.2 \%, 0.3 \%, 0.4 \%, 0.7 \%$ and $1.0 \%$ ) along with the scattering and the absorption coefficients were carried out across the IGP from 1 June until 20 June 2016, prior to onset of the ISM over central and northern India, using the instrumented research aircraft of the National Remote Sensing Centre (NRSC) of the ISRO. The details of the sorties, base stations and instruments used are listed in Table 1. Monthly mean synoptic wind conditions, using the European Centre for Medium-Range Weather Forecasts (ECMWF) ERA-Interim (ECMWF Reanalysis) product during June 2016 at two altitude levels, (a) $975 \mathrm{hPa}$ (near to the surface) and (b) $700 \mathrm{hPa}$ (free-tropospheric altitude), are shown in Fig. 1. The near-surface advection of a marine air mass is seen over the peninsula and regions south of $\sim 25^{\circ} \mathrm{N}$, while to the north of it and at higher levels, a dry continental air mass is advected from the northwest. As per the India Meteorological Department (IMD), the onset of the ISM during 2016 was on 8 June 2016 at the southern peninsular coast of the state of Kerala which advanced to the eastern IGP by 10 June and reached the central IGP by 19 June. 

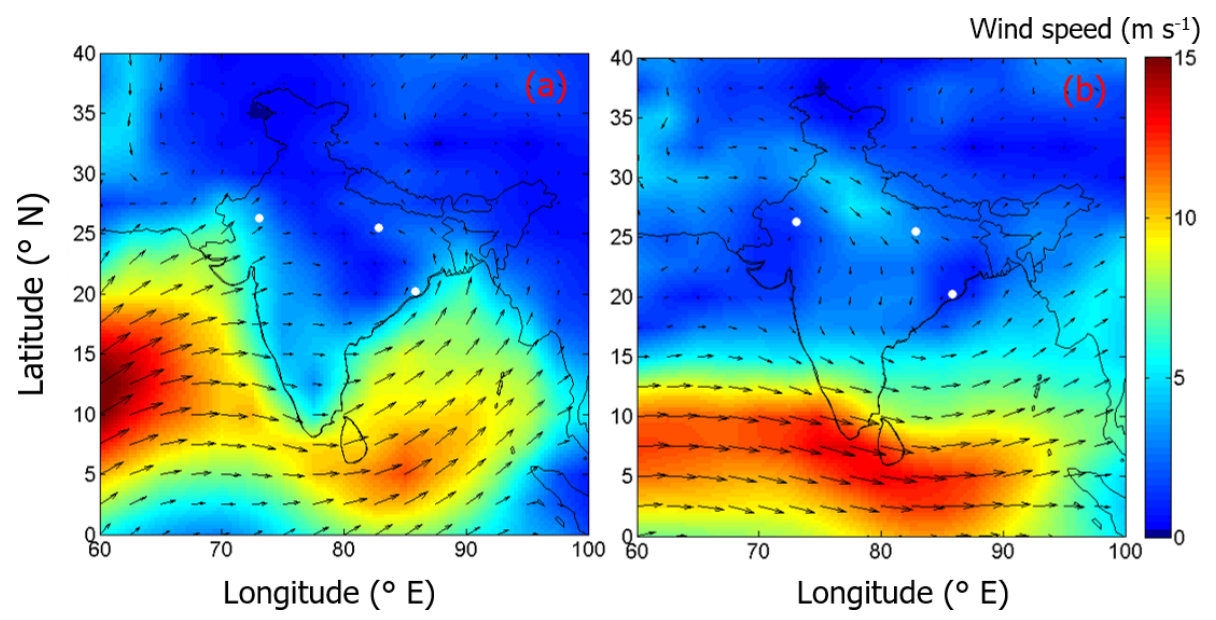

Figure 1. The strength and direction of winds at (a) $975 \mathrm{hPa}$ and (b) $700 \mathrm{hPa}$ over the Indian subcontinent during June 2016. White dots indicate the base stations. Wind data are from the ERA-Interim reanalysis.

Table 1. Details of the sorties, including the dates, instruments used and rain events for the campaign period.

\begin{tabular}{|c|c|c|c|c|c|}
\hline $\begin{array}{l}\text { Region } \\
\text { (base station) }\end{array}$ & $\begin{array}{l}\text { Coordinates } \\
\left({ }^{\circ} \mathrm{N},{ }^{\circ} \mathrm{E}\right)\end{array}$ & $\begin{array}{r}\text { Height, m } \\
\text { (a.m.s.l.) }\end{array}$ & $\begin{array}{l}\text { Period } \\
(2016)\end{array}$ & Remarks & Instruments \\
\hline $\begin{array}{l}\text { Eastern IGP } \\
(\mathrm{BBR})\end{array}$ & $20.24,85.81$ & 42 & 1-5 June & Rain on 3 and 4 June after the sorties & \multirow{3}{*}{$\begin{array}{l}\text { CCN counter (model CCN-100, } \\
\text { DMT) } \\
\text { Condensation particle counter } \\
\text { (model 3776, TSI) } \\
\text { Aethalometer (model AE33, } \\
\text { Magee Scientific) } \\
\text { Nephelometer (model 3563, } \\
\text { TSI) }\end{array}$} \\
\hline $\begin{array}{l}\text { Central IGP } \\
\text { (VNS) }\end{array}$ & $25.45,82.85$ & 81 & 8-13 June & Rain on 7 June evening & \\
\hline $\begin{array}{l}\text { Western IGP } \\
\text { (JDR) }\end{array}$ & $26.25,73.04$ & 219 & 17-20 June & No rain & \\
\hline
\end{tabular}

Aircraft measurements were carried out from three base stations, each representing distinct regions of the IGP: (i) Bhubaneswar $\left(\mathrm{BBR}, 20.24^{\circ} \mathrm{N}, 85.81^{\circ} \mathrm{E}, 42 \mathrm{~m}\right.$ a.m.s.l.) - a semi-urban coastal location at the eastern end of the IGP, (ii) Varanasi (VNS, $25.45^{\circ} \mathrm{N}, 82.85^{\circ} \mathrm{E}, 81 \mathrm{~m}$ a.m.s.1.) representing the aerosol-laden (polluted) central IGP and (iii) Jodhpur (JDR, 26.25 $\mathrm{N}, 73.04^{\circ} \mathrm{E}, 219 \mathrm{~m}$ a.m.s.1.) representing a semi-arid location on the western IGP, which receives a large amount of mineral dust, lofted from the adjoining deserts as well as advected from western Asia and eastern Africa. The base stations along with the direction of sorties for different days of the campaign are shown in Fig. 2a. The instruments aboard and the local weather conditions are listed in Table 1. As seen from the table, pre-monsoon showers occurred on $2 \mathrm{~d}$ at BBR and on $1 \mathrm{~d}$ at VNS. The campaign was executed just prior to the onset of the ISM at each of the base station.

All aircraft sorties were carried out late in the morning and early afternoon (10:00-14:00 IST; IST stands for Indian standard time, which is $5.5 \mathrm{~h}$ ahead of UTC) to ensure that the planetary boundary layer (PBL) is fully evolved and aerosols are well mixed within the PBL. During this period, which is summer over the Indian region, the PBL would be quite deep as the thermal convections would be strong providing a thorough vertical mixing. Estimated from the NCEP/NCAR (National Centers for Atmospheric Prediction/National Center for Atmospheric Research) global reanalysis product at $0.25^{\circ} \times 0.25^{\circ}$ grid resolution data, mean PBL heights at local noon over the IGP regions for the flight sortie days were $1.4 \pm 0.2,2.3 \pm 0.5$ and $1.3 \pm 0.5 \mathrm{~km}$ for BBR, VNS and JDR, respectively (Vaishya et al., 2018). Due to the unpressurised mode of operation of the aircraft, the ceiling altitude of airborne measurements was $\sim 4 \mathrm{~km}$ a.m.s.l. In all, 14 sorties were undertaken, with five from each base station, except from JDR, where only four sorties were completed. Each sortie was undertaken for a period of $\sim 3.5 \mathrm{~h}$, during which the measurements were made at six altitude levels $-\sim 500$, $1000,1500,2000,2500$ and $3000 \mathrm{~m}$ above the ground level (a.g.l.), following the "staircase pattern" shown in Fig. $2 b$ (Babu et al., 2016). Accordingly, after takeoff, the aircraft climbed to the first level (500 m a.g.1.), stabilised its attitude and flew at that level for $\sim 30$ min during which it covered a horizontal distance of $\sim 150 \mathrm{~km}$ before climbing up to the next higher level and retracing the path. This procedure was 

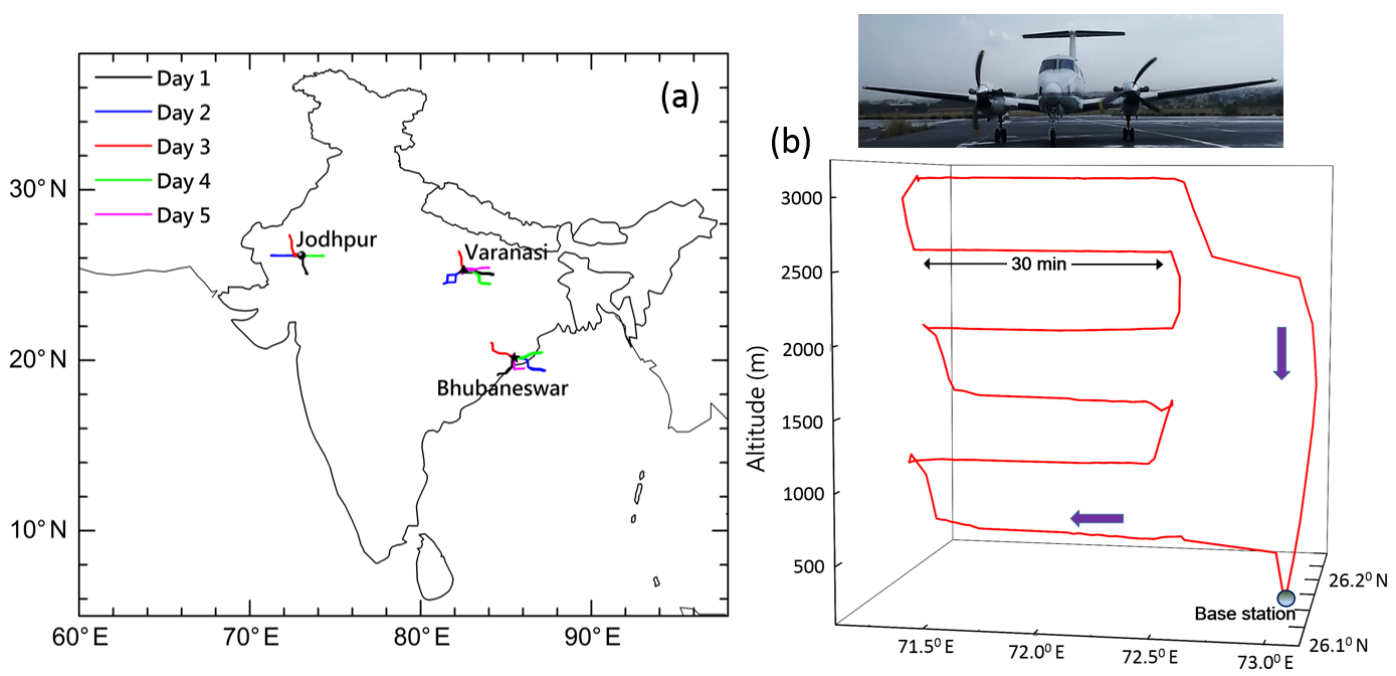

Figure 2. (a) Base stations for the aircraft sorties with the track of each sortie superimposed. (b) A typical sortie pattern (staircase) which represents all the sorties carried out during the experiment and the photograph of NRSC aircraft.

repeated until the highest level (ceiling altitude) was reached, after which the aircraft descended to the base. The sorties were repeated on consecutive days, except that on each day the aircraft proceeded to a different radial direction from the base, as shown in Fig. 2a, so that the five sorties together provided a gross picture of the aerosol properties around the base station within a radius of about $150 \mathrm{~km}$.

\subsection{Measurements}

Ambient air was aspirated to the instruments using a solid diffuser inlet (University of Hawai ${ }^{i}$ ) maintained at isokinetic flow conditions, as detailed in Babu et al. (2016), with a volumetric flow rate of $70 \mathrm{~L} \mathrm{~min}^{-1}$ (litres per minute), for the aircraft's average cruising speed of $300 \mathrm{~km} \mathrm{~h}^{-1}$. The efficacy of the inlet to sample aerosols below $4 \mu \mathrm{m}$, under such conditions, was demonstrated during the DC-8 Inlet Characterization Experiment (McNaughton et al., 2007). Further details of the experiment setup are explained in Babu et al. (2016) and Vaishya et al. (2018). The air, aspirated through this inlet, is then fed to different instruments through a manifold. Aerosol instruments onboard were calibrated prior to and after the campaign to ensure consistency in the measurements. Concurrent time and space coordinates were logged continuously using a high-resolution global positioning system (GPS).

The CCN concentration at different supersaturations was measured every second using a continuous-flow CCN counter (model CCN-100, Droplet Measurement Technologies) by feeding the aspirated air continuously to the cylindrical column of the counter at a constant flow rate of $0.5 \mathrm{Lmin}^{-1}$, where it is exposed to the desired supersaturations. Details of the principle of operation of the CCN counter are available elsewhere (Roberts and Nenes, 2005;
Lance et al., 2006). Aerosols, according to their composition and size, having a critical supersaturation less than the effective supersaturation inside the column, will spontaneously grow into a droplet as they exit the column. These droplets are counted with an optical counter using a laser with a $650 \mathrm{~nm}$ wavelength. During each set of measurements, the supersaturation was varied through $0.2 \%, 0.3 \%, 0.4 \%$, $0.7 \%$ and $1.0 \%$ over a cycle of $30 \mathrm{~min}$, and the cycle is repeated at each altitude level so that a complete $\mathrm{CCN}$ spectra (of CCN vs. supersaturation) is available at every altitude level. In the present study, the CCN concentrations never exceeded $5000 \mathrm{~cm}^{-3}$, and hence the correction for water vapour depletion (Lathem and Nenes, 2011) is not applied. Pressure correction was done to the set supersaturation at each altitude layer depending upon the change in pressure between ambient and calibration pressure (Lance et al., 2009). Data points during the supersaturation transition are excluded due to the inherent ambiguity in the stability of the attained supersaturation. The measured $\mathrm{CCN}$ concentration has a maximum uncertainty of $10 \%$ (Rose et al., 2008).

The total aerosol number concentration was measured using an ultrafine condensation particle counter (model 3776, TSI), developed by Stolzenburg and McMurry (1991). It measures $\mathrm{CN}$ of a diameter of $2.5 \mathrm{~nm}$ and above, with a time base of $1 \mathrm{~min}$. The aspirated air is continuously fed at $1.5 \mathrm{~L} \mathrm{~min}^{-1}$ and mixed with clean sheath air, which is saturated with butanol vapour while passing through a saturator. The resultant flow is passed through a condenser where a sudden cooling result in the condensation of butanol vapour onto aerosols occurs due to supersaturation, and the droplets are counted using a counter working with a laser diode at $650 \mathrm{~nm}$. Further details of the instrument and its adaptability for aircraft-based experiments are explained by Takegawa et al. (2017). 


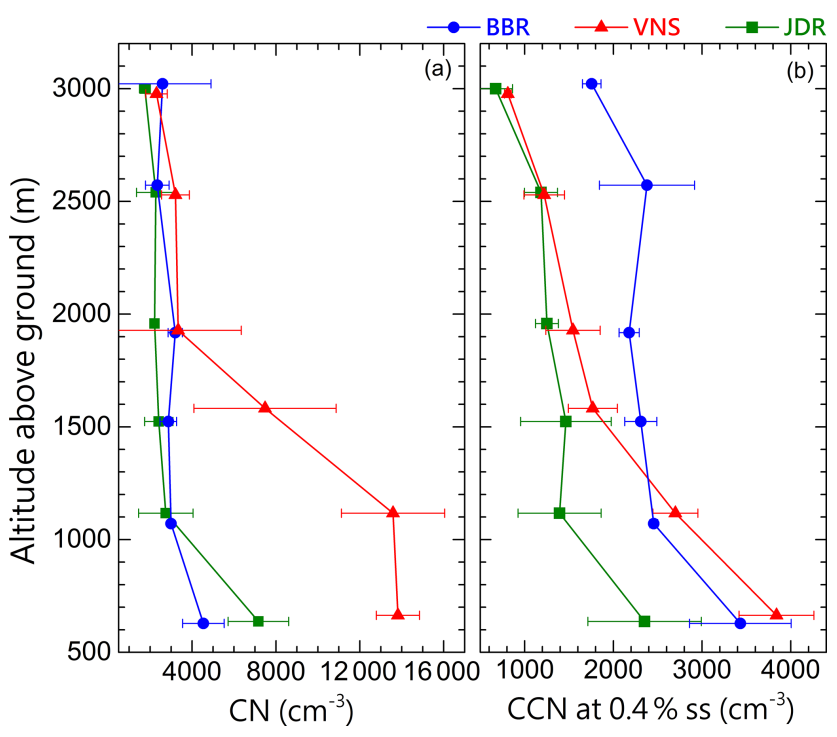

Figure 3. Vertical distribution of regionally averaged (a) aerosol number concentration $(\mathrm{CN})$ and $(\mathbf{b}) \mathrm{CCN}$ number concentration across the IGP. The circle, triangle and square represent the BBR, VNS, and JDR IGP regions, respectively. Error bars represent the standard deviation around the mean values.

Aerosol absorption measurements at seven different wavelengths $(370,470,520,590,660,880$ and $950 \mathrm{~nm})$ were carried out using a DualSpot AE33 Aethalometer (Magee Scientific) (Drinovec et al., 2015) which works on the principle of a filter-based optical attenuation technique (Hansen et al., 1984). A filter loading artefact of the instrument is corrected in real time as explained by Drinovec et al. (2015). Absorption measurements were corrected for a change in flow rate at high altitudes following Moorthy et al. (2004). Optical attenuation at $880 \mathrm{~nm}$ is used to estimate the black carbon (BC) mass concentration using the specific absorption cross section value $\left(7.77 \mathrm{~m}^{2} \mathrm{~g}^{-1}\right)$. The Integrating Nephelometer (model 3563, TSI) measured the scattering coefficient $\left(\sigma_{\text {sca }}\right)$ at 450,550 and $700 \mathrm{~nm}$ wavelengths. Scattering measurements were corrected for non-linearity in the angular truncation error following Anderson and Ogren (1998).

For the $\mathrm{CCN}$ data analysis, the initial 5 min of data at each altitude level were discarded considering the stability of the measurements, and the data were averaged for every minute. Hence a minimum of $20 \mathrm{~min}$ of usable data comprising five supersaturations is available for each altitude level. Measurements of $\mathrm{CN}$, spectral scattering and spectral absorption were also synchronised to the $1 \mathrm{~min}$ averaged $\mathrm{CCN}$ data. Thus, for each region (eastern, western and central IGP), five vertical profiles of $\mathrm{CCN}$ and $\mathrm{CN}$ concentration and scattering and absorption coefficients were obtained.

\section{Results and discussion}

\subsection{Vertical distribution of $\mathrm{CN}$ and $\mathrm{CCN}$}

Vertical profiles of $\mathrm{CN}$ and $\mathrm{CCN}$ concentrations (at $0.4 \%$ supersaturation) for the three subregions of the IGP are shown in Fig. 3. Each profile is an average of all the sorties carried out from the base station. Significant differences are seen below $\sim 1.5 \mathrm{~km}$, which represents the well-mixed region within the PBL, and are attributed to the subregional scale emissions. As such, the $\mathrm{CN}$ concentrations are up by nearly a factor of 2 at the central IGP (VNS) compared to the eastern or western ends of the IGP, owing to the large-scale anthropogenic activities in the central IGP. Beyond $\sim 2 \mathrm{~km}$ altitude, the $\mathrm{CN}$ concentrations remain quite comparable in magnitude across the entire IGP with similar vertical variations.

In contrast to this, there is a significant difference in the aerosol type across the IGP (attributable to the source heterogeneity), as revealed by the $\mathrm{CCN}$ concentration as revealed by the CCN concentration in Fig. 3b, especially in the free troposphere (above $2 \mathrm{~km}$ ). Near to the surface, where the local source impacts dominate, the CCN concentration is the least over the arid western IGP (JDR), followed by the industrialised eastern IGP (BBR), with the VNS depicting the highest concentration. At all the subregions, $\mathrm{CCN}$ concentrations decrease towards higher altitudes. However, there is a sharp difference in the decreasing pattern, with the concentrations over the VNS falling off very rapidly and almost merging with the profile over the arid region (JDR). The decrease is rather inconspicuous over BBR. The CCN concentration, though decreasing initially with heights up to $1 \mathrm{~km}$, was more or less steady above $1 \mathrm{~km}$, suggesting the prevalence of more hygroscopic particles aloft.

Irrespective of all these, the $\mathrm{CCN}$ concentrations remain high (1000 to $>2000 \mathrm{~cm}^{-3}$ at $0.4 \%$ supersaturation), even at $3 \mathrm{~km}$ altitude, which is above the base of monsoon clouds (Das et al., 2017). This will have strong implications in cloud modification, as has been established elsewhere (Andreae et al., 2004; Rosenfeld et al., 2008); however, their influence on the monsoon rainfall over the study region has not yet been quantified. Based on the aircraft observations during CAIPEEX over Hyderabad $\left(17.45^{\circ} \mathrm{N}, 78.38^{\circ} \mathrm{E}\right)$ in southern India, Padma Kumari et al. (2017) reported the suppression of warm rain process due to the presence of high $\mathrm{CCN}$ concentration. During the collaborative Regional Aerosol Warming Experiment and the Ganges Valley Aerosol Experiment (GVAX), Gogoi et al. (2015) have reported CN and CCN (at $0.46 \%$ supersaturation) concentrations of $\sim 2500$ and $\sim$ $1100 \mathrm{~cm}^{-3}$, respectively, for June 2011 , from a high-altitude station ( $\sim 2 \mathrm{~km}$ a.m.s.l.), Nainital in the central Himalayas. The high $\mathrm{CN}$ and $\mathrm{CCN}$ concentrations observed in this study is in line with values reported from Nainital, which is an optimal high-altitude site to study regional (IGP) as well as transported aerosol characteristics over the IGP. In another study over the Loess plateau in China during July-August months, 
Li et al. (2015) reported high concentrations of $\mathrm{CN}$ and $\mathrm{CCN}$, peaking within the PBL and decreasing with increasing altitude. Lance et al. (2009) reported a CCN number concentration varying from $\sim 200$ to more than $10000 \mathrm{~cm}^{-3}$ during the Gulf of Mexico Atmospheric Composition and Climate Study (GoMACCS) aircraft campaign, over a heavily polluted region with power plants and ship channels of Houston. Local aerosol sources play a significant role in determining the vertical structure during the period when high convective mixing prevails, while advection has a strong influence on the spatial variation of altitudinal distribution above the PBL. From Fig. 1, it is clear that there is an advection of marine air mass near the ground level $(975 \mathrm{hPa})$ in both the eastern and western regions of the IGP and intruding into the central IGP. However, northwesterlies from the continental region pass through the free-tropospheric heights $(700 \mathrm{hPa})$ of the central IGP before reaching the eastern coast. In short, the $\mathrm{CCN}$ concentration at cloud-forming heights, which is a critical parameter in deciding the cloud droplet number concentration, is quite abundant over the IGP, decreasing spatially from the eastern IGP to the western IGP especially above the PBL.

\subsection{Altitudinal dependence of $\mathrm{CCN}-\mathrm{CN}$ association}

Aerosol number size distribution and composition are known to show vertical variations (Zhang et al., 2011; Li et al., 2015). Hence it is imperative to examine the altitudinal dependency of $\mathrm{CCN}$ on $\mathrm{CN}$ and its region-specific nature. In Fig. 4, the altitude variation of the $\mathrm{CCN}-\mathrm{CN}$ relationship is presented for a constant supersaturation $(0.4 \%)$ as a scatter plot of CCN vs. CN for the eastern (top panel), central (middle panel) and western IGP (bottom panel) regions, respectively. Each point in the figure corresponds to the mean concentration at a particular altitude level above the ground (identified by the colour) for each day of observation (identified by the shape of the point). The striking linear relationship over the entire altitude range at the eastern IGP (BBR; top panel) clearly indicates the vertical homogeneity in aerosol composition in this region. The deviation of a couple of points at the highest altitude from this relationship indicates the presence of different aerosol types aloft. This is supported by the air mass back trajectories which are examined in Sect. 3.4.

The $\mathrm{CCN}-\mathrm{CN}$ relationship is quite nebulous over the central IGP, which is a hotspot of anthropogenic activities, as revealed by the large scatter of the points in Fig. 4b. The scatter at the lower altitudes indicates the influence of local source impacts, which also leads to a large variation in the concentration as revealed by the large standard deviations. The association becomes better and stronger again as we move to the western IGP (JDR), where mineral dust is the most dominant constituent. The linear association between $\mathrm{CCN}$ and $\mathrm{CN}$ for low-to-moderate $\mathrm{CCN}$ concentrations (up to $\sim 4000 \mathrm{~cm}^{-3}$ ) becomes non-linear for higher

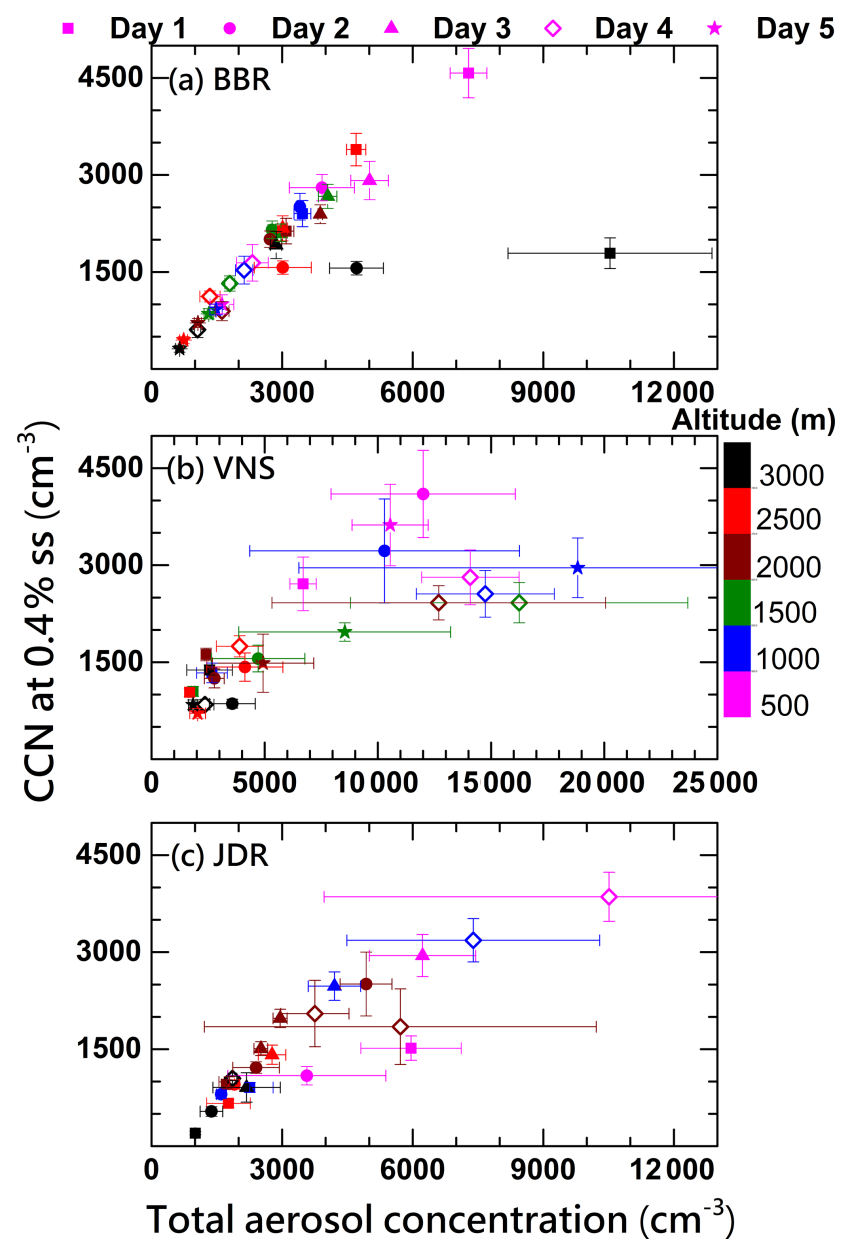

Figure 4. Association between the total $\mathrm{CN}$ and $\mathrm{CCN}$ number concentration at $0.4 \%$ supersaturation for the (a) eastern IGP (BBR), (b) central IGP (VNS) and (c) western IGP (JDR) for each day of observation at all the observation heights. Colour codes indicate the altitude above ground level, while symbols represent the day of observation. Error bars represent the standard deviation around the mean values.

concentrations $\left(\mathrm{CCN}>5000 \mathrm{~cm}^{-3}\right)$. The $\mathrm{CCN}$ concentration tends to saturate at about $4000 \mathrm{~cm}^{-3}$ (for $0.4 \%$ supersaturation), even though the $\mathrm{CN}$ concentration increases beyond $10000 \mathrm{~cm}^{-3}$. A similar saturation of the $\mathrm{CCN}$ concentration associated with large $\mathrm{CN}$ concentrations was reported by Roy et al. (2017) at $\sim 2.2 \mathrm{~km}$ a.m.s.l. in the eastern Himalayas.

To further investigate the above hypothesis of the role of local emissions in weakening the relationship between $\mathrm{CCN}$ and $\mathrm{CN}$ over the central IGP, the variation of the $\mathrm{CCN}$ number concentration at $0.4 \%$ supersaturation with $\mathrm{BC}$ mass concentration are examined in Fig. 5. For this, the concurrent $\mathrm{BC}$ mass concentration measurements carried out from the same platform are used. The central IGP showed the highest absorption coefficient (column averaged) of $26 \pm 9 \mathrm{Mm}^{-1}$, followed by the western $\left(16 \pm 2 \mathrm{Mm}^{-1}\right)$ and eastern $(15 \pm$ $3 \mathrm{Mm}^{-1}$ ) IGP (Vaishya et al., 2018). It is interesting to note 


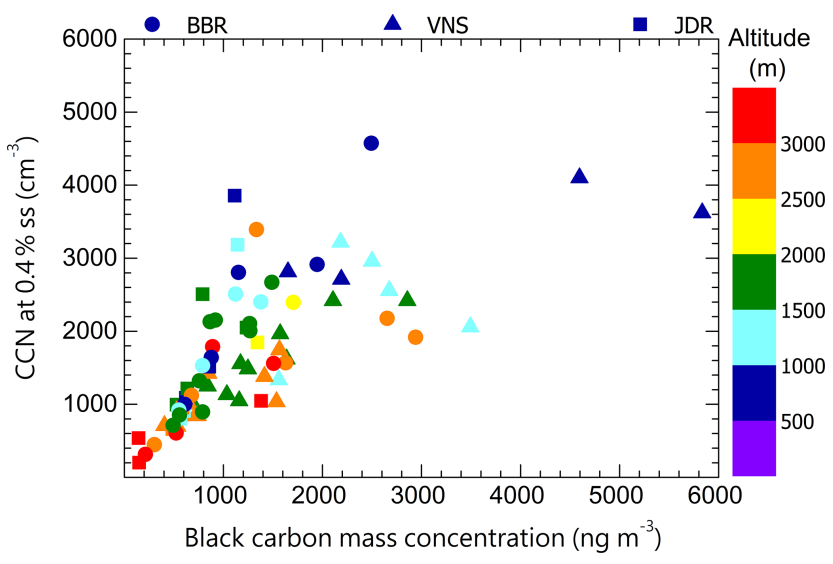

Figure 5. Association of $\mathrm{CCN}$ number concentration at $0.4 \%$ supersaturation with $\mathrm{BC}$ mass concentration over the eastern (BBR; circle), central (VNS; triangle) and western (JDR; square) IGP regions. Colour codes indicate the altitude of observation.

that the linear relationship is maintained for low-to-moderate concentrations of BC (up to around $1000 \mathrm{ng} \mathrm{m}^{-3}$, which occurs mostly above the PBL), while significant scatter occurs for higher values of $\mathrm{BC}$ (exceeding $2000 \mathrm{ng} \mathrm{m}^{-3}$ ), which occurs mostly in the lower altitudes, supporting the hypothesis. Similar deviations in the $\mathrm{CCN}-\mathrm{CN}$ relationship with respect to altitude have also been reported by Srivastava et al. (2013) over the central IGP region using aircraft measurements, where they attributed it to the impact of local anthropogenic emissions.

\subsection{CCN spectra and parameterisation for different altitudes}

Using the measurements of $\mathrm{CCN}$ number concentration as a function of supersaturation, the mean $\mathrm{CCN}$ spectra are constructed for different subregions of the IGP and shown in Fig. 6 for different altitudes. In addition to the regional distinctiveness in the $\mathrm{CCN}$ number concentrations seen in Fig. 3, it is interesting to note the rapid levelling off of the spectra with increasing supersaturation at the eastern IGP (represented by BBR, blue lines in Fig. 6), especially above $1 \mathrm{~km}$. This is in contrast to the other two regions, where the CCN concentrations keep on increasing with increasing supersaturation at all heights. This clearly demonstrates a change in the hygroscopicity of aerosols across the IGP, especially in the free troposphere. To quantify this, the $\mathrm{CCN}$ spectra are parameterised by evolving a least-squares fit with Twomey's relation (Twomey, 1959),

$\mathrm{CCN}(\mathrm{ss})=C(\mathrm{ss})^{k}$,

where $\mathrm{CCN}$ (ss) is the number concentration of $\mathrm{CCN}$ at a particular supersaturation (ss) and $C$ and $k$ are empirical coefficients. Lower $k$ values are reported more frequently for marine air mass compared to continental air mass (Twomey and
Wojciechowski, 1969; Khain, 2009). The fine-mode anthropogenic aerosols exhibit high $k$ values, while hygroscopic and larger aerosols like sea salt have low $k$ values (Hegg et al., 1991; Jefferson, 2010). The shape of the CCN spectra, represented by the $k$ values, showed significant altitudinal variations. The altitude variations in the $\mathrm{CCN}$ spectra, which can be due to the variations in aerosol number size distribution, will have an impact on the droplet size distribution of the warm cloud formation (Raga and Jonas, 1995).

The vertical variation of the $k$ values for each region is shown in Fig. 7, which reveals a distinct transformation of the CCN properties of aerosol across the IGP. Over the eastern IGP (which is industrialised and near the coast), $k$ is the least, with a small vertical variation that shows a weak decrease initially and then a weak increase. The arid western IGP shows a very similar vertical variation of $k$, but the values remain consistently higher than those seen for the eastern IGP at all heights. The highest values of $k$ are seen over the central IGP, with a steady increase with altitude. Across the entire IGP, $k$ increases with altitude, indicating a decrease in the hygroscopicity with altitude or a rapid change in the number size distribution. As the CCN concentration at higher supersaturations $(>0.4 \%)$ are mainly governed by the concentration of small particles $(<\sim 70 \mathrm{~nm})$ (Lance et al., 2009), the corresponding high $\mathrm{CCN}$ concentration suggests the presence of a prominent fine-mode aerosol system, which is clearly seen over the entire IGP, especially over the central IGP. The nearflat $\mathrm{CCN}$ spectra at BBR (above $0.4 \%$ supersaturation) indicate the presence of highly soluble or coarse-mode aerosols, such that almost all aerosols are activated at $0.4 \%$ supersaturation itself. Similar observations of low $k$ values $(\sim 0.2)$ are reported by Jayachandran et al. (2017) from a coastal location in peninsular India during the sea breeze regime of the monsoon season, when both the local mesoscale and synoptic circulations bring marine (sea salt) aerosols to the region.

The similarity in the vertical profiles of the $k$ value over the western and eastern regions of the IGP show the presence of the similar nature of $\mathrm{CCN}$ active aerosols over both regions. The reported CCN spectra and $k$ values over the Indian subcontinent at higher altitudes are listed in Table 2 for different aerosol types using both ground-based and aircraft-based platforms. It should be noted that the $k$ values depend on the supersaturation range used for its estimation, and hence the supersaturation range is also mentioned in the table. From the table, it can be seen that the values reported from the central Himalayas ( $2 \mathrm{~km}$ a.m.s.l.) are similar to the present observations over the central IGP at similar altitudes. The central Himalayas experience an air mass from the IGP as well as semi-arid regions of western Asia during pre-monsoon periods, and Dumka et al. (2015) reported a mean $k$ value of $\sim 0.58$ for June 2011 during the RAWEX-GVAX campaign. The current observations show $k$ values above 0.51 for altitudes above $2 \mathrm{~km}$ over the central IGP. In the present study, the $k$ values estimated for the altitude $2-3 \mathrm{~km}$ a.g.l. are in the range $0.25-0.32$ and $0.31-0.46$ above the eastern and 


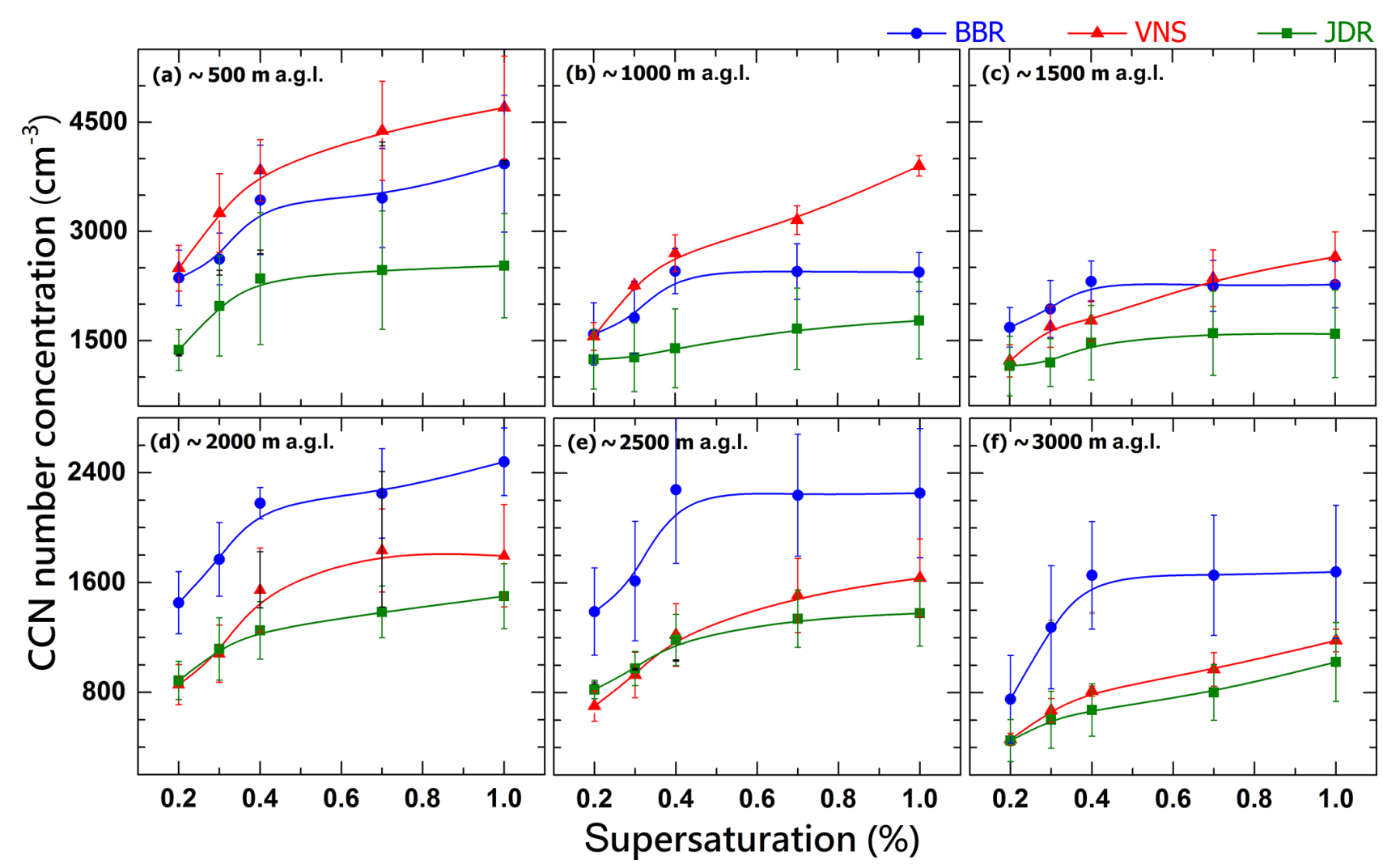

Figure 6. Mean CCN spectra at six altitudes levels over different subregions of the IGP. The error bars indicate the standard deviation around the mean. The points correspond to measurements, while the lines are the empirical fits. The circle, triangle and square represent the eastern (BBR), central (VNS) and western (JDR) IGP subregions, respectively.

western IGP, respectively. Roy et al. (2017) reported a mean $k$ value of $\sim 0.38$ during the pre-monsoon period over the eastern Himalayas when the air mass reached the site from the IGP as well as semi-arid regions of western Asia. Examining the CCN spectra at the cloud base $(\sim 1600 \mathrm{~m})$ during the CAIPEEX campaign (October 2011) over peninsular India, Varghese et al. (2016) reported high $k$ values $(0.72)$ associated with polluted conditions and low $k$ values $(0.25)$ during clean conditions. Flat CCN spectra with low $k$ values observed in this study over the eastern and western IGP indicate the high $\mathrm{CCN}$-active nature of the aerosols.

\subsection{CCN activation efficiency: vertical structure and variation across the IGP}

$\mathrm{CCN}$ activation efficiency is the ratio of the $\mathrm{CCN}$ number concentration at a particular supersaturation to the total $\mathrm{CN}$ concentration. This ratio has been estimated as a function of altitude for each of the sorties, and the mean vertical profiles are shown in Fig. 8a for $0.4 \%$ supersaturation. Similar to the altitude variation of $k$ shown in Fig. 7 over distinct regions of the IGP, the activation efficiency is the least over the central IGP (VNS) and the highest in the eastern IGP (BBR), with that over JDR coming in between. At all the stations, the efficiency remains low within the PBL (below $1.5 \mathrm{~km}$ ) where the local-source impacts are rather substantial. Above the PBL, it either increases or remains steady with altitude before decreasing again above $2.5 \mathrm{~km}$, probably due to different aerosol types (less hygroscopic, finer particles) at the higher levels. The low CCN efficiency over VNS is associated with the presence of a higher concentration of $\mathrm{BC}$ $\left(>4000 \mathrm{ng} \mathrm{m}^{-3}\right)$ and $\mathrm{CN}$ number $\left(>10000 \mathrm{~cm}^{-3}\right)$, indicating a pollution surrogate from anthropogenic sources modifying the $\mathrm{CCN}$ activation.

The variation of $k$ with $\mathrm{CCN}$ activation efficiency at $0.4 \%$ supersaturation for the eastern IGP (BBR, circle), central IGP (VNS, triangle) and western IGP (JDR, square) are shown in Fig. 8b. High values of $k$ are observed with a low CCN activation efficiency and vice versa, showing an inverse relationship between the two parameters. CCN efficiency and $k$ over the desert region vary from $\sim 20 \%$ to $65 \%$ and $\sim 0.2$ to 0.7 , respectively. A similar inverse association between $\mathrm{CCN}$ efficiency and $k$ is reported by Hegg et al. (1991) and Jayachandran et al. (2017). High $k$ values are due to the dominant presence of small or less soluble particles in the aerosol system, which in turn reduce the CCN efficiency. However, over the central IGP, very low CCN efficiency $(<20 \%)$ values were observed with low $k$ values $(\sim 0.4)$, which is not in 


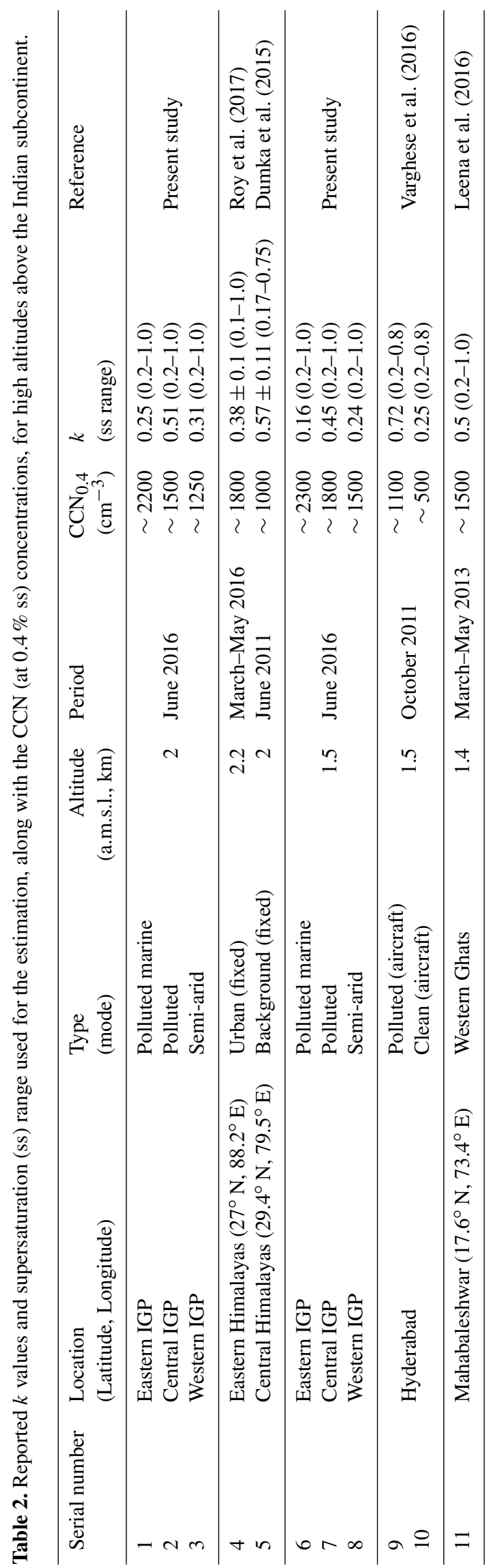

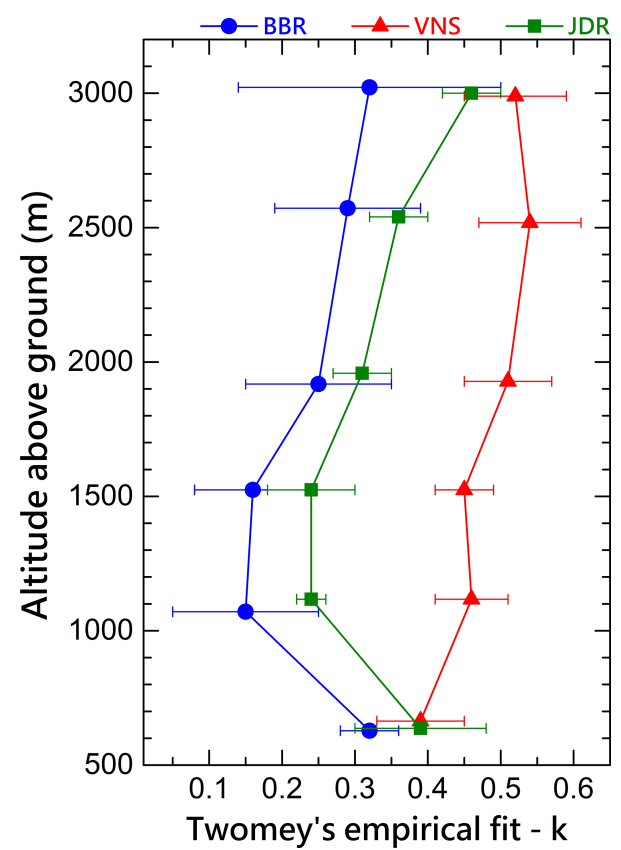

Figure 7. Altitude variation of $k$ (Twomey's empirical fit) over the eastern (BBR; circle), central (VNS; triangle) and western (JDR; square) IGP regions. Error bars represent the standard deviation of the fit.
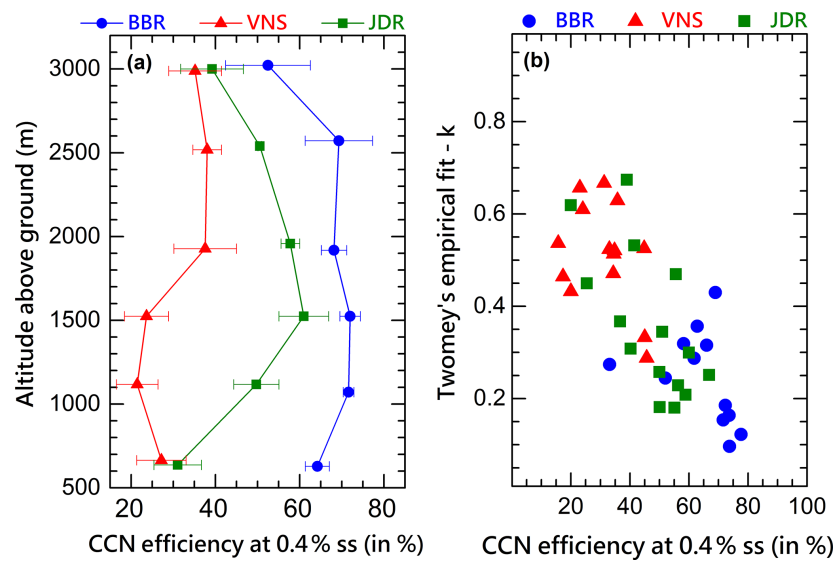

Figure 8. Vertical distribution of the (a) mean $\mathrm{CCN}$ activation efficiency at $0.4 \%$ supersaturation and (b) variation of $k$ values with the corresponding $\mathrm{CCN}$ efficiency at $0.4 \%$ supersaturation over the eastern (BBR; circle), central (VNS; triangle) and western (JDR; square) IGP regions. Error bars represent the standard error of the mean.

line with the general inverse relationship. These cases were observed within the PBL, indicating a CCN-inactive aerosol system even at high $(>0.8 \%)$ supersaturations. At high altitudes $(>3 \mathrm{~km}$ ) over the IGP, Srivastava et al. (2013) have reported an aerosol size distribution peaking below $\sim 40 \mathrm{~nm}$ due to new particle formation (NPF) events and cloud processing. Rose et al. (2017) have reported the significant role 
of NPF in CCN activation above PBL especially during the wet season at Chacaltaya (5240 m a.m.s.l.), Bolivia. In the present study, the role of cloud processing or in-cloud scavenging for low CCN efficiency and flat CCN spectra (low $k$ ) at cloud forming heights cannot be neglected.

Based on measurements at the mean sea level and at $1 \mathrm{~km}$ above ground level, Jayachandran et al. (2018) have shown the vertical heterogeneity in the CCN efficiency and CCN spectra during the ISM on the southern coast of India. Li et al. (2015) have shown that the anthropogenic influences can cause a strong variation in CCN efficiency from $10 \%$ to $70 \%$ from the near-ground level to about $4.5 \mathrm{~km}$ over China during the Asian summer monsoon season. More than $50 \%$ of the aerosols are $\mathrm{CCN}$ active over the regions other than central IGP, which indicates the dominant role of natural aerosols in warm cloud droplet activation over the subcontinent just prior to the ISM season. The air mass traversing through the polluted continental regions is responsible for the lowering of $\mathrm{CCN}$ activation efficiency at free-tropospheric heights over the eastern IGP. The back-trajectory analysis of an air mass reaching 500 and $3000 \mathrm{~m}$ over BBR (figure not included) clearly showed that the particles reaching $3000 \mathrm{~m}$ have a purely continental history of passing across the IGP from the arid regions of western India and western Asia, whereas those reaching $500 \mathrm{~m}$ pass over the oceanic region of the Bay of Bengal before arriving at the location. This distinctiveness in the air mass history at higher altitudes also causes the scatter in the $\mathrm{CCN}-\mathrm{CN}$ association seen in Fig. 4. The significant influence of the nature of the air mass on $\mathrm{CCN}$ activation over the Indian region is illustrated by the closure studies carried out by Srivastava et al. (2013) at various altitudes. Jayachandran et al. (2017) have reported a higher CCN activation efficiency for marine air masses than continental air masses from ground-based observations from peninsular India during the ISM. Within the PBL, including near the ground level, CCN efficiency is very high over the eastern IGP (coast), which will support the cloud droplet formation with a sharp droplet size distribution.

One of the striking features emerging from this study is the high CCN efficiency over the arid region of the western IGP, which is reported for the first time. This region is known for its dust dominance (both locally generated and advected from the Middle East and eastern Africa). Though pure dust is water inactive, its $\mathrm{CCN}$ efficiency will enhance when coated or mixed with soluble salts like sulfates and nitrates (Kelly et al., 2007). Though Feingold et al. (1999) have shown that coarse-mode dust aerosols can act as a giant $\mathrm{CCN}$ and initiate drizzle formation, their number concentration is far less numerous, especially at high altitudes (Padma Kumari et al., 2013). Thus, the observations of moderately high CCN activation efficiency, lower values of $k$ and a higher concentration of $\mathrm{CCN}$ over the desert region are interesting and in need of discussion. Figure 9 shows air mass back trajectories for $5 \mathrm{~d}$ and arriving at 500, 1500 and $3000 \mathrm{~m}$ a.m.s.l. above the (a) eastern IGP (BBR), (b) central IGP (VNS) and (c) west- ern IGP (JDR). In Fig. 9c, it can be seen that the air mass reaching JDR (conducive for dust advection) has a significant history over the northwestern Arabian Sea, and hence it would also carry significant moisture. It is known that the presence of hygroscopic salt aerosols can catalyse the reaction of dust with acidic gases (Tobo et al., 2010), changing its hygroscopicity. Thus, the air mass reaching the desert region, having a strong marine component, could enhance the activation efficiency of the aerosols. A strong convection in the lower atmosphere will also take salt aerosols to the atmosphere from the regional dry salt lakes. Bègue et al. (2015) have reported a CCN efficiency of $\sim 70 \%$ for $0.2 \%$ supersaturation over the Netherlands during a dust transport event due to the accumulation of solute particles on dust. The present study shows that about $66 \%$ of the total aerosols in the PBL of the western IGP (JDR) were activated as CCN at $1 \%$ supersaturation.

The coastal location BBR (Fig. 9a) is strongly under the influence of a marine air mass. It travels considerably across the Indian mainland initially, enters the Bay of Bengal, turns and then arrives at BBR; thus it would be moisture laden and contain sea salt particles. On the other hand, at the central IGP, irrespective of the history of the air masses, they have to travel considerable distances across the mainland and are thus conducive for the advection of anthropogenic aerosols. Additionally they lose a significant amount of moisture they have acquired from the ocean. Thus, VNS is under the influence of local emissions, which includes hydrophobic particles such as BC, which is also in the fine-size range, with all of this resulting in the highest values of $k$ and lowest values of CCN activation efficiency of the three IGP subregions. Vertical profiles of CCN efficiency over VNS for the first day of observation ( 8 June) when the air mass was from the marine region (Bay of Bengal) and the mean picture for the other days (when the air mass was continental) are shown in Fig. 10a, respectively, with dotted and continuous bold lines. The significant increase in the activation efficiency during marine-air-mass conditions is very conspicuous.

At BBR, there have been two episodes of pre-monsoon precipitation on 4 and 5 June 2018 (before the sorties), with an accumulated rainfall of 58 and $8 \mathrm{~mm}$. The vertical profile of CCN activation efficiency over BBR averaged for measurements before and after rainfall is shown in bold and dotted lines, respectively, in Fig. 10b. There is a decrease (though weak) in the activation efficiency (especially below the cloud level at $2 \mathrm{~km}$ ) after the precipitation, probably due to the removal of hygroscopic aerosols by the precipitation. Even though the $\mathrm{CCN}$ efficiency is found to be slightly reduced below $2 \mathrm{~km}$, the CCN activation efficiency is found to be higher above $2 \mathrm{~km}$ compared to observations before the rainfall. Near the ground level, $\mathrm{CCN}$ concentration (mean \pm standard deviation) reduced from $3431 \pm 572$ to $1320 \pm 454 \mathrm{~cm}^{-3}$ and from $1755 \pm 105$ to $460 \pm 209 \mathrm{~cm}^{-3}$ at $\sim 3 \mathrm{~km}$ a.g.l. After the rainfall, a reduction $(<10 \%)$ is seen 

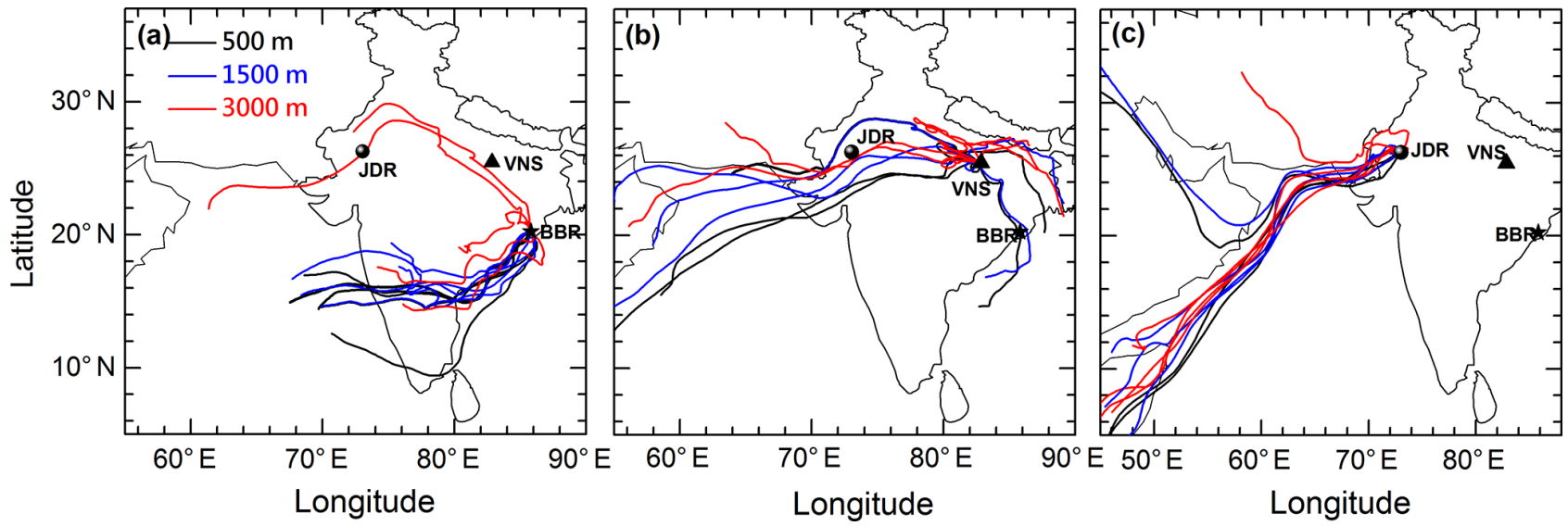

Figure 9. Air mass back trajectories for $5 \mathrm{~d}$ at $500 \mathrm{~m}$ (black), $1500 \mathrm{~m}$ (blue) and $3000 \mathrm{~m}$ (red) a.m.s.l. over the (a) eastern IGP (BBR), (b) central IGP (VNS) and (c) western IGP (JDR) during the campaign period.

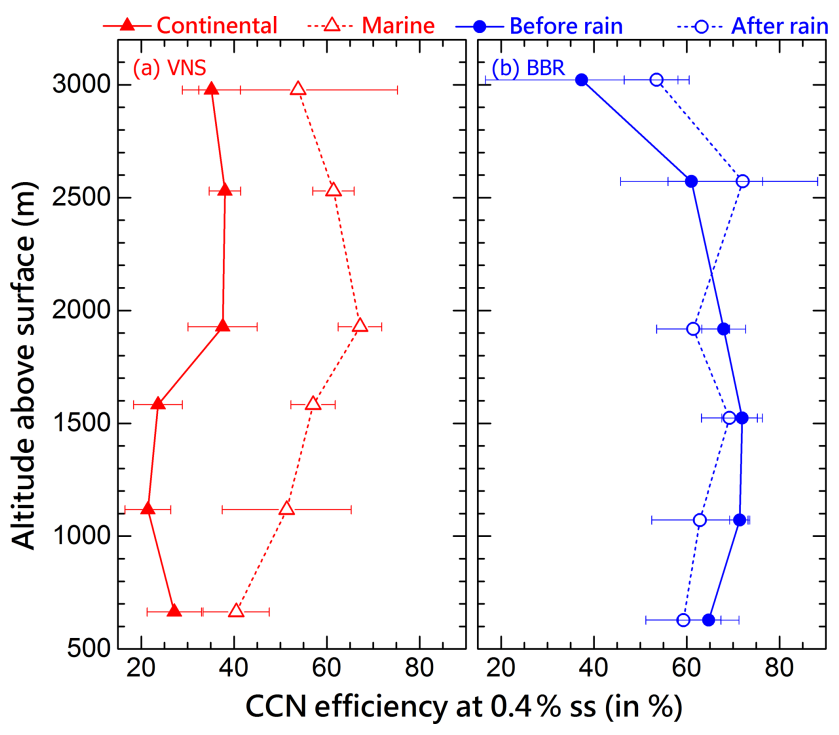

Figure 10. Altitude variation of CCN efficiency at $0.4 \%$ supersaturation showing the effect of (a) distinct air mass (continental - solid line; marine - broken line) at the central IGP (VNS) and (b) rainfall (before - solid line; after - broken line) at the eastern IGP (BBR).

in the $\mathrm{CCN}$ efficiency over BBR; meanwhile, there is a large diminution in the number concentration of $\mathrm{CN}$ and $\mathrm{CCN}$.

The theoretical framework of the wet-scavenging process accounts for nucleation, gravitational and inertial impacts, and turbulence scavenging mechanisms (Pruppacher and Klett, 1980). However, uncertainties and difficulties still exist in attributing the observational evidence of the wet scavenging of aerosols to different scavenging mechanisms, especially in the case of moving air parcels. The efficiency of below-cloud scavenging (wash out) mainly depends on the number size distribution of both aerosols and raindrops, while the in-cloud scavenging (rain out) depends mainly on the solubility of the aerosols (Garrett et al., 2006). The de- crease in CCN concentration over BBR after the rainfall and the high CCN efficiency seen in the present study indicate the highly soluble nature of the aerosol system prevailing over the region. The difference in CCN activation efficiency at different altitude levels before and after rainfall reinstates the difference in the aerosol types at different altitudes. One of the possibilities for the observed CCN efficiency is that the rainfall has removed coarser and hygroscopic particles by wet scavenging, resulting in the reduction of the $\mathrm{CCN}$ activation efficiency below $2 \mathrm{~km}$. Cloud processing broadening the aerosol distribution as reported by Flossmann et al. (1987) may be enhancing the CCN activation efficiency above $2 \mathrm{~km}$. However, the effect of cloud formation and further rainfall on $\mathrm{CCN}$ characteristics needs further investigation. The modification in $\mathrm{CCN}$ efficiency over VNS and BBR underlines the role of the specific type of the air mass and rainfall in determining the vertical structure of $\mathrm{CCN}$ activation in a short duration.

\section{5 $\mathrm{CCN}$ and aerosol optical properties}

Concurrent measurements of aerosol scattering and absorption coefficients during the campaign provided an opportunity to examine possible links between $\mathrm{CCN}$ and the optical properties of aerosols. Liu and Li (2014) and Jefferson (2010) have illustrated the potential of using aerosol optical properties as a proxy and prognostic variable for studying the CCN properties. Liu and $\mathrm{Li}$ (2014) have used the scattering aerosol index (AI), which is the product of the scattering coefficient (at $450 \mathrm{~nm}$ ) and scattering Ångström exponent, to link the aerosol scattering properties to a $\mathrm{CCN}$ concentration. Following their approach, we have estimated AI as $\mathrm{AI}=\sigma_{\text {sca }}(450) \times \alpha_{\text {sca }}$, where $\sigma_{\text {sca }}(450)$ is the scattering coefficient at $450 \mathrm{~nm}$, estimated from the Nephelometer data, and $\alpha_{\text {sca }}$ is the Ångström exponent, estimated over the wavelength range 450,550 and $700 \mathrm{~nm}$ by adapting a least-squares 


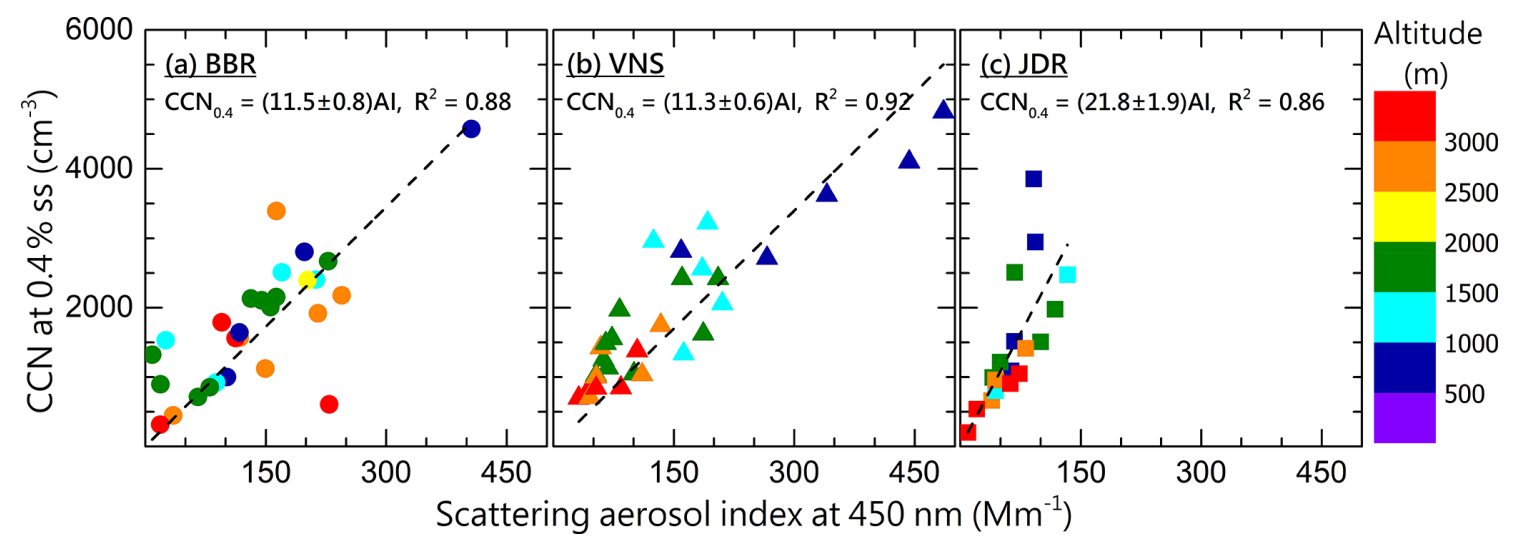

Figure 11. Association between the total scattering $\mathrm{AI}$ at $450 \mathrm{~nm}$ and $\mathrm{CCN}$ number concentration at $0.4 \%$ supersaturation for the (a) eastern (BBR), (b) central (VNS) and (c) western (JDR) IGP regions. The colour indicates the altitude of measurement. Dashed lines represent the linear least-squares fit to the points for each region. Regression slopes and squared correlation coefficients are written in each panel.

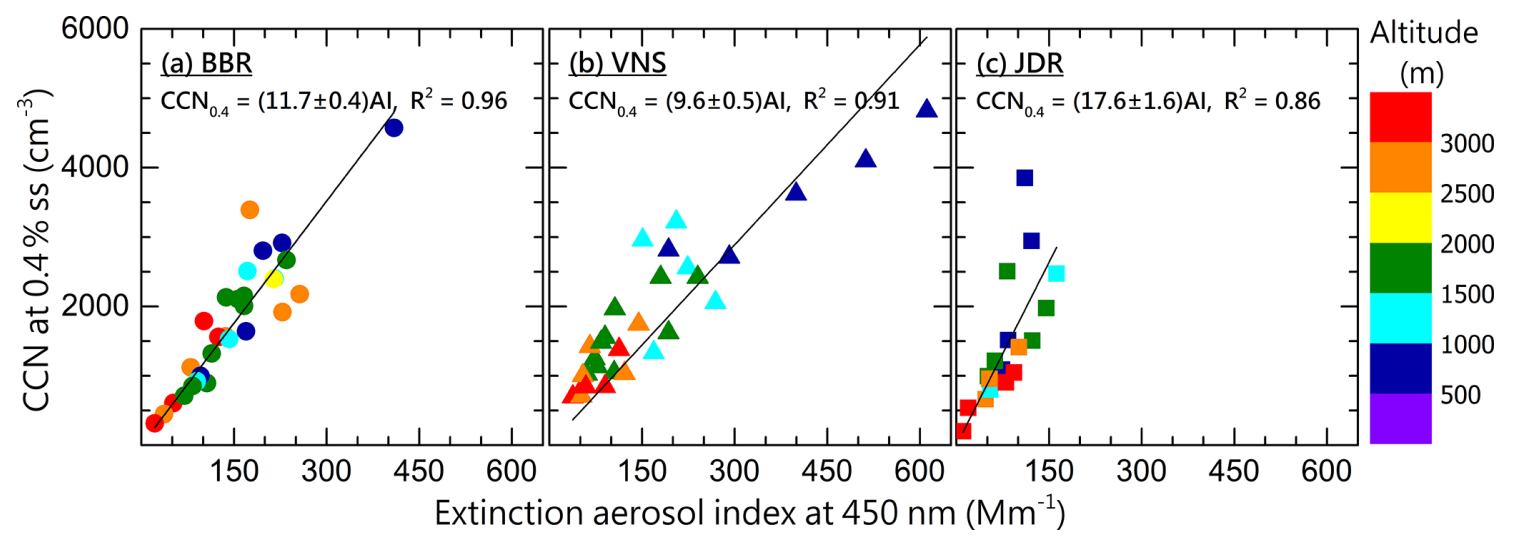

Figure 12. Association between the extinction $\mathrm{AI}$ at $450 \mathrm{~nm}$ and $\mathrm{CCN}$ number concentration at $0.4 \%$ supersaturation for the (a) eastern (BBR), (b) central (VNS) and (c) western (JDR) IGP regions. The colour indicates the altitude of measurement. The solid lines represent the linear least-squares fit to the points for each region. Regression slopes and squared correlation coefficients are written in each panel.

fit to the relation

$\sigma_{\text {sca }}(\lambda)=\sigma_{0} \lambda^{-\alpha_{\text {sca }}}$

The scatter plots of CCN concentration at $0.4 \%$ supersaturation against scattering AI are shown in Fig. 11, with panels from left to right representing the eastern, central and western IGP, along with the corresponding altitudes of measurement, indicated by the colour code. Linear least-squares fits to the points through the origin (implying that all the scattering aerosols contribute to $\mathrm{CCN}$ concentration) are also shown in the figure along with the fit parameters. Very good linear dependencies emerge from the figure for all the stations across the IGP, though the slope appears to be region specific.

The highest slope is observed at the least anthropogenically impacted and dust-dominated western IGP, while the slope values are comparable over the anthropogenically influenced eastern and central IGP. As scattering AI is a product of the scattering coefficient and scattering Ångström ex- ponent, it carried signatures of total particulate loading and the size distribution.

A scatter between the extinction aerosol index and CCN concentration at $0.4 \%$ supersaturation is generated and shown in Fig. 12. If absorption contributed insignificantly to the extinction, then this plot would not differ significantly from Fig. 11. However, it can be seen in Fig. 12 that there is a significant reduction in the slope over the western and central IGP (JDR and VNS). This indicates the reduction in CCN activation due to absorbing aerosols, probably dust. However, there is no remarkable change in the slope over BBR, which might be due to the reduced concentration of dust (as most of it get removed as dust is advected across the IGP and also due to the mixing of dust with other more hygroscopic aerosol species as it ages in the atmosphere). There is an increase in the correlation coefficient over the eastern IGP also when we consider aerosol absorption, which might be indicative of the contribution of these aerosols to CCN activation, probably due to co-emitted or co-existing soluble inorganic particles. 
Examining Fig. 11 along with the $\mathrm{CN}$ profile shown in Fig. 3a, it can be seen that the higher slope (21.8) at JDR is due to the large-size dust particles there, even though the $\mathrm{CN}$ concentrations at JDR and BBR are comparable, except at the lowest altitude. The coarse-size distribution would lead to the smaller scattering Ångström exponent resulting in low scattering AI values. It is interesting to note that scattering AI values at JDR are low, though the scattering coefficient values are higher than at BBR (Vaishya et al., 2018). However, the slope at BBR is nearly half of that seen at JDR, despite it having the highest activation efficiency. On similar lines, it appears that the size distribution of aerosols over VNS has more fine particles (higher Ångström exponent but lower activation efficiency). Thus, the size distribution and chemistry of the aerosol influence the relationship between the scattering aerosol index and $\mathrm{CCN}$ concentration. This dependency is useful in developing an empirical relationship connecting $\mathrm{CCN}$ and light scattering properties at least on a regionspecific scale. The number concentration of Aitken mode aerosols, especially the aerosols in the 60-100 $\mathrm{nm}$ range, and its composition is the main factor in governing the variability in CCN properties, while the relative dominance of accumulation mode aerosols will be determining the scattering properties. Figure 11 demonstrates the strong relationship that exists between the aerosol scattering properties and $\mathrm{CCN}$ concentration in the vertical column over the IGP. The relationship between $\mathrm{CCN}$ and aerosol optical properties further implied the use of satellite-retrieved AOD products in the region, which are now matured and fairly accurate, and a model-generated aerosol profile aided by ground- and spacebased lidar in predicting $\mathrm{CCN}$.

\section{Conclusions}

The extensive characterisation of the CCN altitude distribution and its spatial variation across the IGP has been carried out for the first time using in situ measurements aboard an instrumented aircraft just prior to the onset of the Indian summer monsoon. The results concluded below form a significant step towards the characterisation and understanding of the ACI during the Indian summer monsoon, though the impact on cloud microphysics needs further investigation.

Spatial heterogeneity in total aerosol concentration exists over the IGP with high concentrations $\left(>13000 \mathrm{~cm}^{-3}\right.$ ), over the central IGP (near to the ground level) and the least over the western IGP, while its vertical variation remains the same above the planetary boundary layer (PBL) at all regions.

A high CCN concentration (above $1000 \mathrm{~cm}^{-3}$ at $0.4 \%$ supersaturation) is observed up to $2.5 \mathrm{~km}$ across the IGP, indicating the significant possibility of aerosol indirect effects.

The central IGP shows a higher CCN activation efficiency above the PBL $(>1.5 \mathrm{~km})$ than within it, despite the latter having high $\mathrm{CN}$ and $\mathrm{CCN}$ concentrations indicating the ac- tivation of aerosols as $\mathrm{CCN}$ is suppressed by freshly emitted aerosols, mostly from anthropogenic sources.

The high CCN activation efficiency, $\sim 61 \%$ at $0.4 \%$ supersaturation, at $\sim 1.5 \mathrm{~km}$ above the ground level is observed over the dust-dominated western IGP. This high CCN activation efficiency of dust aerosols can modify the cloud microphysics over the region, hence affecting the precipitation pattern as well as the regional radiation balance.

It is seen that while precipitation reduces the $\mathrm{CCN}$ activation efficiency below cloud level, the advection of the marine air mass enhances $\mathrm{CCN}$ efficiency, even over arid regions.

An empirical relationship between the $\mathrm{CCN}$ activation and optical properties of aerosols has further implied the use of satellite-retrieved AOD products and the model-generated aerosol profile aided by ground- and space-based lidar in predicting $\mathrm{CCN}$ over the region.

Data availability. Data are available upon request from the contact author, Surendran Nair Suresh Babu (s_sureshbabu@vssc.gov.in).

Author contributions. SNSB, SKS and KKM conceptualised the experiment and finalised the methodology. SNSB, VNJ, AV and MMG were responsible for the data collection on board the aircraft. VNJ carried out the scientific analysis of the data, supported by SNSB, VSN and AV. VNJ drafted the paper. SNSB, KKM and SKS carried out the review and editing of the paper.

Competing interests. The authors declare that they have no conflict of interest.

Special issue statement. This article is part of the special issue "Interactions between aerosols and the South West Asian monsoon". It is not associated with a conference.

Acknowledgements. This study was carried out as part of the combined South-West Asian Aerosol-Monsoon Interactions and Regional Aerosol Warming Experiment (SWAAMI-RAWEX) campaign. We thank the director of the National Remote Sensing Centre (NRSC) in Hyderabad and the Aerial Services and Digital Mapping Area (AS \& DMA) for providing the aircraft support for this experiment. Aditya Vaishya was supported by the Department of Science and Technology of the government of India, through its INSPIRE Faculty Scheme. Details of the aircraft data used in the present study and the point of contact are available at http://spl.gov.in (last access: 14 January 2020) under "Research Themes" and "Aerosol, Trace gases and Radiative Forcing Branch". The RAWEX project is supported by ISRO (Indian Space Research Organisation) and the SWAAMI project is supported by MoES (Ministry of Earth Science). 
Review statement. This paper was edited by B. V. Krishna Murthy and reviewed by two anonymous referees.

\section{References}

Anderson, T. L. and Ogren, J. A.: Determining aerosol radiative properties using the TSI 3563 integrating nephelometer, Aerosol Sci. Technol., 29, 57-69, 1998.

Andreae, M. O., Rosenfeld, D., Artaxo, P., Costa, A., Frank, G., Longo, K., and Silva-Dias, M. A. F. D.: Smoking rain clouds over the Amazon, Science, 303, 1337-1342, 2004.

Asa-Awuku, A., Moore, R. H., Nenes, A., Bahreini, R., Holloway, J. S., Brock, C. A., Middlebrook, A. M., Ryerson, T. B., Jimenez, J. L., Decarlo, P. F., Hecobian, A., Weber, R. J., Stickel, R., Tanner, D. J., and Huey, L. G.: Airborne cloud condensation nuclei measurements during the 2006 Texas Air Quality Study, J. Geophys. Res.-Atmos., 116, D11201, https://doi.org/10.1029/2010JD014874, 2011.

Babu, S. S., Manoj, M. R., Moorthy, K. K., Gogoi, M. M., Nair, V. S., Kompalli, S. K., Satheesh, S. K., Niranjan, K., Ramagopal, K., Bhuyan, P. K., and Singh, D.: Trends in aerosol optical depth over Indian region: Potential causes and impact indicators, J. Geophys. Res.-Atmos., 118, 11794-11806, https://doi.org/10.1002/2013JD020507, 2013.

Babu, S. S., Nair, V. S., Gogoi, M. M., and Krishna Moorthy, K.: Seasonal variation of vertical distribution of aerosol single scattering albedo over Indian sub-continent: RAWEX aircraft observations, Atmos. Environ., 125, 312-323, https://doi.org/10.1016/j.atmosenv.2015.09.041, 2016.

Badarinath, K. V. S., Sharma, A. R., Kaskaoutis, D. G., Kharol, S. K., and Kambezidis, H. D.: Solar dimming over the tropical urban region of Hyderabad, India: Effect of increased cloudiness and increased anthropogenic aerosols, J. Geophys. Res.-Atmos., 115, D21208, https://doi.org/10.1029/2009JD013694, 2010.

Bègue, N., Tulet, P., Pelon, J., Aouizerats, B., Berger, A., and Schwarzenboeck, A.: Aerosol processing and $\mathrm{CCN}$ formation of an intense Saharan dust plume during the EUCAARI 2008 campaign, Atmos. Chem. Phys., 15, 3497-3516, https://doi.org/10.5194/acp-15-3497-2015, 2015.

Bhattu, D. and Tripathi, S. N.: Inter-seasonal variability in sizeresolved CCN properties at Kanpur, India, Atmos. Environ., 85, 161-168, https://doi.org/10.1016/j.atmosenv.2013.12.016, 2014.

Boucher, O., Randall, D., Artaxo, P., Bretherton, C., Feingold, G., Forster, P., Kerminen, V.-M., Kondo, Y., Liao, H., Lohmann, U., Rasch, P., Satheesh, S. K., Sherwood, S., Stevens, B., and Zhang, X. Y.: Clouds and Aerosols. In: Climate Change 2013: The Physical Science Basis. Contribution of Working Group I to the Fifth Assessment Report of the Intergovernmental Panel on Climate Change, UK and New York, 2013.

Das, S. K., Golhait, R. B., and Uma, K. N.: Clouds vertical properties over the Northern Hemisphere monsoon regions from CloudSat-CALIPSO measurements, Atmos. Res., 183, 73-83, 2017.

Dey, S. and Di Girolamo, L.: A decade of change in aerosol properties over the Indian subcontinent, Geophys. Res. Lett., 38, L14811, https://doi.org/10.1029/2011GL048153, 2011.

Di Girolamo, L., Bond, T. C., Bramer, D., Diner, D. J., Fettinger, F., Kahn, R. A., Martonchik, J. V., Ramana, M. V., Ramanathan,
V., and Rasch, P. J.: Analysis of Multi-angle Imaging SpectroRadiometer (MISR) aerosol optical depths over greater India during winter 2001-2004, Geophys. Res. Lett., 31, L23115, https://doi.org/10.1029/2004GL021273, 2004.

Drinovec, L., Močnik, G., Zotter, P., Prévôt, A. S. H., Ruckstuhl, C., Coz, E., Rupakheti, M., Sciare, J., Müller, T., Wiedensohler, A., and Hansen, A. D. A.: The "dual-spot" Aethalometer: an improved measurement of aerosol black carbon with realtime loading compensation, Atmos. Meas. Tech., 8, 1965-1979, https://doi.org/10.5194/amt-8-1965-2015, 2015.

Dumka, U. C., Bhattu, D., Tripathi, S. N., Kaskaoutis, D. G., and Madhavan, B. L.: Seasonal inhomogeneity in cloud precursors over Gangetic Himalayan region during GVAX campaign, Atmos. Res., 155, 158-175, https://doi.org/10.1016/j.atmosres.2014.11.022, 2015.

Dusek, U., Frank, G., Hildebrandt, L., Curtius, J., Schneider, J., Walter, S., Chand, D., Drewnick, F., Hings, S., and Jung, D.: Size matters more than chemistry for cloud-nucleating ability of aerosol particles, Science, 312, 1375-1378, 2006.

Farmer, D. K., Cappa, C. D., and Kreidenweis, S. M.: Atmospheric processes and their controlling influence on cloud condensation nuclei activity, Chem. Rev., 115, 4199-4217, 2015.

Feingold, G., Cotton, W. R., Kreidenweis, S. M., and Davis, J. T.: The impact of giant cloud condensation nuclei on drizzle formation in stratocumulus: Implications for cloud radiative properties, J. Atmos. Sci., 56, 4100-4117, 1999.

Flossmann, A. I., Pruppacher, H. R., and Topalian, J. H.: A theoretical study of the wet removal of atmospheric pollutants. Part II: The uptake and redistribution of $\left(\mathrm{NH}_{4}\right)_{2} \mathrm{SO}_{4}$ particles and $\mathrm{SO}_{2}$ gas simultaneously scavenged by growing cloud drops, J. Atmos. Sci., 44, 2912-2923, 1987.

Garrett, T., Avey, L., Palmer, P., Stohl, A., Neuman, J., Brock, C., Ryerson, T., and Holloway, J.: Quantifying wet scavenging processes in aircraft observations of nitric acid and cloud condensation nuclei, J. Geophys. Res.-Atmos., 111, D23S51, https://doi.org/10.1029/2006JD007416, 2006.

Gogoi, M. M., Babu, S. S., Jayachandran, V., Moorthy, K. K., Satheesh, S. K., Naja, M., and Kotamarthi, V. R.: Optical properties and CCN activity of aerosols in a high-altitude Himalayan environment: Results from RAWEX-GVAX, J. Geophys. Res.-Atmos., 120, 2453-2469, https://doi.org/10.1002/2014JD022966, 2015.

Hansen, A. D. A., Rosen, H., and Novakov, T.: The Aethalometer - an instrument for the real-time measurement of optical absorption by aerosol particles, Sci. Total Environ., 36, 191-196, 1984.

Hegg, D. A., Radke, L. F., and Hobbs, P. V.: Measurements of Aitken nuclei and cloud condensation nuclei in the marine atmosphere and their relation to the DMS-cloud-climate hypothesis, J. Geophys. Res., 96, 18727-18733, 1991.

Hoppel, W., Dinger, J., and Ruskin, R.: Vertical profiles of $\mathrm{CCN}$ at various geographical locations, J. Atmos. Sci., 30, 1410-1420, 1973.

Hudson, J. G. and Xie, Y.: Vertical distributions of cloud condensation nuclei spectra over the summertime northeast Pacific and Atlantic Oceans, J. Geophys. Res.-Atmos., 104, 30219-30229, 1999.

IPCC: Climate Change 2013: The Physical Science Basis, Contribution of Working Group I to the Fifth Assessment Report of the 
Intergovernmental Panel on Climate Change, UK and New York, 1535 pp., 2013.

Jayachandran, V., Nair, V. S., and Babu, S. S.: CCN characteristics over a tropical coastal station during south-west monsoon: observations and closure studies, Atmos. Environ., 164, 299-308, 2017.

Jayachandran, V., Nair, V. S., and Babu, S. S.: CCN activation properties at a tropical hill station in Western Ghats during south-west summer monsoon: Vertical heterogeneity, Atmos. Res., 214, 3645, 2018.

Jefferson, A.: Empirical estimates of $\mathrm{CCN}$ from aerosol optical properties at four remote sites, Atmos. Chem. Phys., 10, 68556861, https://doi.org/10.5194/acp-10-6855-2010, 2010.

Jethva, H., Satheesh, S. K., and Srinivasan, J.: Seasonal variability of aerosols over the Indo Gangetic basin, J. Geophys. Res., 110, D21204, https://doi.org/10.1029/2005JD005938, 2005.

Jurányi, Z., Gysel, M., Weingartner, E., Bukowiecki, N., Kammermann, L., and Baltensperger, U.: A 17 month climatology of the cloud condensation nuclei number concentration at the high alpine site Jungfraujoch, J. Geophys. Res.-Atmos., 116, D10204, https://doi.org/10.1029/2010JD015199, 2011.

Kelly, J. T., Chuang, C. C., and Wexler, A. S.: Influence of dust composition on cloud droplet formation, Atmos. Environ., 41, 2904-2916, 2007.

Khain, A. P.: Notes on state-of-the-art investigations of aerosol effects on precipitation: a critical review. Environ. Res. Lett., 4, 015004, https://doi.org/10.1088/1748-9326/4/1/015004, 2009

Konwar, M., Das, S., Deshpande, S., Chakravarty, K., and Goswami, B.: Microphysics of clouds and rain over the Western Ghat, J. Geophys. Res.-Atmos., 119, 6140-6159, 2014.

Lance, S., Nenes, A., Medina, J., and Smith, J. N.: Mapping the Operation of the DMT Continuous Flow CCN Counter, Aerosol Sci. Technol., 40, 242-254, https://doi.org/10.1080/02786820500543290, 2006.

Lance, S., Nenes, A., Mazzoleni, C., Dubey, M. K., Gates, H., Varutbangkul, V., Rissman, T. A., Murphy, S. M., Sorooshian, A., and Flagan, R. C.: Cloud condensation nuclei activity, closure, and droplet growth kinetics of Houston aerosol during the Gulf of Mexico Atmospheric Composition and Climate Study (GoMACCS), J. Geophys. Res.-Atmos., 114, D00F15, https://doi.org/10.1029/2008JD011699, 2009.

Lathem, T. L. and Nenes, A.: Water vapor depletion in the DMT continuous-flow CCN chamber: Effects on supersaturation and droplet growth, Aerosol Sci. Technol., 45, 604-615, 2011.

Lawrence, M. G. and Lelieveld, J.: Atmospheric pollutant outflow from southern Asia: a review, Atmos. Chem. Phys., 10, 11017 11096, https://doi.org/10.5194/acp-10-11017-2010, 2010.

Leena, P., Pandithurai, G., Anilkumar, V., Murugavel, P., Sonbawne, S., and Dani, K.: Seasonal variability in aerosol, CCN and their relationship observed at a high altitude site in Western Ghats, Meteorol. Atmos. Phys., 128, 143-153, 2016.

Li, J., Yin, Y., Li, P., Li, Z., Li, R., Cribb, M., Dong, Z., Zhang, F., Li, J., Ren, G., Jin, L., and Li, Y.: Aircraft measurements of the vertical distribution and activation property of aerosol particles over the Loess Plateau in China, Atmos. Res., 155, 73-86, https://doi.org/10.1016/j.atmosres.2014.12.004, 2015.

Li, Z., Lau, W. M., Ramanathan, V., Wu, G., Ding, Y., Manoj, M., Liu, J., Qian, Y., Li, J., and Zhou, T.: Aerosol and monsoon climate interactions over Asia, Rev. Geophys.,, 54, 866-929, 2016.
Liu, J. and Li, Z.: Estimation of cloud condensation nuclei concentration from aerosol optical quantities: influential factors and uncertainties, Atmos. Chem. Phys., 14, 471-483, https://doi.org/10.5194/acp-14-471-2014, 2014.

McNaughton, C. S., Clarke, A. D., Howell, S. G., Pinkerton, M., Anderson, B., Thornhill, L., Hudgins, C., Winstead, E., Dibb, J. E., Scheuer, E., and Maring, H.: Results from the DC-8 inlet characterization experiment (DICE): Airborne versus surface sampling of mineral dust and sea salt aerosols, Aerosol Sci. Technol., 41, 136-159, https://doi.org/10.1080/02786820601118406, 2007.

Moorthy, K. K., Babu, S. S., Sunilkumar, S. V., Gupta, P. K., and Gera, B. S.: Altitude profiles of aerosol BC, derived from aircraft measurements over an inland urban location in India, Geophys. Res. Lett., 31, 1-4, https://doi.org/10.1029/2004GL021336, 2004.

Moorthy, K. K., Satheesh, S., and Kotamarthi, V.: Evolution of aerosol research in India and the RAWEX-GVAX: An overview, Curr. Sci., 11, 53-75, 2016.

Nair, V. S., Babu, S. S., Manoj, M. R., Moorthy, K. K., and Chin, M.: Direct radiative effects of aerosols over South Asia from observations and modeling, Clim. Dynam., 49, 1411-1428, 2017.

Padma Kumari, B., Londhe, A. L., Daniel, S., and Jadhav, D. B.: Observational evidence of solar dimming: Offsetting surface warming over India, Geophys. Res. Lett., 34, L21810, https://doi.org/10.1029/2007GL031133, 2007.

Padma Kumari, B., Maheskumar, R., Morwal, S., Harikishan, G., Konwar, M., Kulkarni, J., and Goswami, B.: Aircraft observations of elevated pollution layers near the foothills of the Himalayas during CAIPEEX-2009, Q. J. Roy. Meteor. Soc., 139, 625-638, https://doi.org/10.1002/qj.1989, 2013.

Padma Kumari, B., Maheskumar, R., Anand, V., and Axisa, D.: Microphysical characteristics of convective clouds over ocean and land from aircraft observations, Atmos. Res., 195, 62-71, 2017.

Paramonov, M., Kerminen, V.-M., Gysel, M., Aalto, P. P., Andreae, M. O., Asmi, E., Baltensperger, U., Bougiatioti, A., Brus, D., Frank, G. P., Good, N., Gunthe, S. S., Hao, L., Irwin, M., Jaatinen, A., Jurányi, Z., King, S. M., Kortelainen, A., Kristensson, A., Lihavainen, H., Kulmala, M., Lohmann, U., Martin, S. T., McFiggans, G., Mihalopoulos, N., Nenes, A., O’Dowd, C. D., Ovadnevaite, J., Petäjä, T., Pöschl, U., Roberts, G. C., Rose, D., Svenningsson, B., Swietlicki, E., Weingartner, E., Whitehead, J., Wiedensohler, A., Wittbom, C., and Sierau, B.: A synthesis of cloud condensation nuclei counter (CCNC) measurements within the EUCAARI network, Atmos. Chem. Phys., 15, 12211-12229, https://doi.org/10.5194/acp-15-12211-2015, 2015.

Prabha, T. V., Karipot, A., Axisa, D., Kumari, B. P., Maheskumar, R. S., Konwar, M., Kulkarni, J. R., and Goswami, B. N.: Scale interactions near the foothills of Himalayas during CAIPEEX, J. Geophys. Res.-Atmos., 117, D10203, https://doi.org/10.1029/2011JD016754, 2012.

Pruppacher, H. R. and Klett, J. D.: Microphysics of clouds and precipitation, Nature, 284, 88, https://doi.org/10.1038/284088b0, 1980.

Raga, G. and Jonas, P.: Vertical distribution of aerosol particles and $\mathrm{CCN}$ in clear air around the British Isles, Atmos. Environ., 29, 673-684, 1995. 
Roberts, G. and Nenes, A.: A continuous-flow streamwise thermalgradient CCN chamber for atmospheric measurements, Aerosol Sci. Technol., 39, 206-221, 2005.

Rose, C., Sellegri, K., Moreno, I., Velarde, F., Ramonet, M., Weinhold, K., Krejci, R., Andrade, M., Wiedensohler, A., Ginot, P., and Laj, P.: CCN production by new particle formation in the free troposphere, Atmos. Chem. Phys., 17, 1529-1541, https://doi.org/10.5194/acp-17-1529-2017, 2017.

Rose, D., Gunthe, S. S., Mikhailov, E., Frank, G. P., Dusek, U., Andreae, M. O., and Pöschl, U.: Calibration and measurement uncertainties of a continuous-flow cloud condensation nuclei counter (DMT-CCNC): CCN activation of ammonium sulfate and sodium chloride aerosol particles in theory and experiment, Atmos. Chem. Phys., 8, 1153-1179, https://doi.org/10.5194/acp8-1153-2008, 2008.

Rosenfeld, D., Lohmann, U., Raga, G. B., O’Dowd, C. D., Kulmala, M., Fuzzi, S., Reissell, A., and Andreae, M. O.: Flood or drought: How do aerosols affect precipitation?, Science, 321, 1309-1313, https://doi.org/10.1126/science.1160606, 2008.

Roy, A., Chatterjee, A., Sarkar, C., Das, S. K., Ghosh, S. K., and Raha, S.: A study on aerosol-cloud condensation nuclei (CCN) activation over eastern Himalaya in India, Atmos. Res., 189, 6981, 2017.

Satheesh, S. K., Moorthy, K. K., Babu, S. S., Vinoj, V., and Dutt, C. B. S.: Climate implications of large warming by elevated aerosol over India, Geophys. Res. Lett., 35, https://doi.org/10.1029/2008GL034944, 2008.

Schmale, J., Henning, S., Decesari, S., Henzing, B., Keskinen, H., Sellegri, K., Ovadnevaite, J., Pöhlker, M. L., Brito, J., Bougiatioti, A., Kristensson, A., Kalivitis, N., Stavroulas, I., Carbone, S., Jefferson, A., Park, M., Schlag, P., Iwamoto, Y., Aalto, P., Äijälä, M., Bukowiecki, N., Ehn, M., Frank, G., Fröhlich, R., Frumau, A., Herrmann, E., Herrmann, H., Holzinger, R., Kos, G., Kulmala, M., Mihalopoulos, N., Nenes, A., O'Dowd, C., Petäjä, T., Picard, D., Pöhlker, C., Pöschl, U., Poulain, L., Prévôt, A. S. H., Swietlicki, E., Andreae, M. O., Artaxo, P., Wiedensohler, A., Ogren, J., Matsuki, A., Yum, S. S., Stratmann, F., Baltensperger, U., and Gysel, M.: Long-term cloud condensation nuclei number concentration, particle number size distribution and chemical composition measurements at regionally representative observatories, Atmos. Chem. Phys., 18, 2853-2881, https://doi.org/10.5194/acp-18-2853-2018, 2018.

Singla, V., Mukherjee, S., Safai, P., Meena, G., Dani, K., and Pandithurai, G.: Role of organic aerosols in CCN activation and closure over a rural background site in Western Ghats, India, Atmos. Environ., 158, 148-159, 2017.

Sotiropoulou, R. E. P., Nenes, A., Adams, P. J., and Seinfeld, J. H.: Cloud condensation nuclei prediction error from application of Köhler theory: Importance for the aerosol indirect effect, J. Geophys. Res.-Atmos., 112, https://doi.org/10.1029/2008GL034944, 2007.
Srivastava, M., Tripathi, S. N., Dwivedi, A. K., Dalai, R., Bhattu, D., Bharti, P. K., Jaidevi, J., and Gupta, T.: CCN closure results from Indian Continental Tropical Convergence Zone (CTCZ) aircraft experiment, Atmos. Res., 132-133, 322-331, https://doi.org/10.1016/j.atmosres.2013.05.025, 2013.

Stolzenburg, M. R. and McMurry, P. H.: An ultrafine aerosol condensation nucleus counter, Aerosol Sci. Technol., 14, 48-65, 1991.

Takegawa, N., Iida, K., and Sakurai, H.: Modification and laboratory evaluation of a TSI ultrafine condensation particle counter (Model 3776) for airborne measurements, Aerosol Sci. Technol., 51, 235-245, 2017.

Tobo, Y., Zhang, D., Matsuki, A., and Iwasaka, Y.: Asian dust particles converted into aqueous droplets under remote marine atmospheric conditions, P. Natl. Acad. Sci. USA, 107, 17905-17910, 2010.

Twomey, S.: The nuclei of natural cloud formation part II: The supersaturation in natural clouds and the variation of cloud droplet concentration, Geofisica pura e applicata, 43, 243-249, 1959.

Twomey, S. and Wojciechowski, T. A.: Observations of the geographical variation of cloud nuclei, J. Atmos. Sci., 26, 648-651, 1969.

Vaishya, A., Babu, S. N. S., Jayachandran, V., Gogoi, M. M., Lakshmi, N. B., Moorthy, K. K., and Satheesh, S. K.: Large contrast in the vertical distribution of aerosol optical properties and radiative effects across the Indo-Gangetic Plain during the SWAAMI-RAWEX campaign, Atmos. Chem. Phys., 18, 1766917685, https://doi.org/10.5194/acp-18-17669-2018, 2018.

Varghese, M., Prabha, T. V., Malap, N., Resmi, E., Murugavel, P., Safai, P., Axisa, D., Pandithurai, G., and Dani, K.: Airborne and ground based CCN spectral characteristics: Inferences from CAIPEEX-2011, Atmos. Environ., 125, 324-336, 2016.

Vinoj, V., Rasch, P. J., Wang, H., Yoon, J. H., Ma, P. L., Landu, K., and Singh, B.: Short-term modulation of Indian summer monsoon rainfall by West Asian dust, Nat. Geosci., 7, 308-313, https://doi.org/10.1038/ngeo2107, 2014.

Zhang, F., Wang, Y., Peng, J., Ren, J., Collins, D., Zhang, R., Sun, Y., Yang, X., and Li, Z.: Uncertainty in predicting CCN activity of aged and primary aerosols, J. Geophys. Res.-Atmos., 122, 11736, https://doi.org/10.1002/2017JD027058, 2017.

Zhang, Q., Quan, J., Tie, X., Huang, M., and Ma, X.: Impact of aerosol particles on cloud Formation: Aircraft Measurements in China, Atmos. Environ., 45, 665-672, 2011. 